\title{
Reconstrucción del canon poético en el ensayo de Feijoo
}

\author{
Rodrigo Olay Valdés \\ Instituto Feijoo de Estudios del Siglo XVIII-Universidad de Oviedo
}

CES.XVIII, núm. 23 (2013), págs. 151-194. 


\section{RESUMEN}

Aunque ha pasado desapercibido, lo cierto es que la obra ensayística de Feijoo acoge en su seno un tratado de poética que, si bien fragmentado e incompleto, está todavía por sistematizar y merece atención. Punto de especial relevancia dentro de la poética feijoniana es el catálogo de poetas que cita, y que puede decirnos tanto de sus preferencias poéticas como sus propias aseveraciones sobre retórica y poética. En este trabajo, sometemos a un procedimiento bibliométrico la obra en prosa de Feijoo con vistas a esclarecer cuáles son los poetas que más cita y que implicaciones cabe extraer de ello.

Palabras clave

Feijoo, Poética, Canon.

Abstract

Feijoo's writings include in their own a treatise of poetics that has been unknown and disregarded. In spite of this fact, Feijoo's ideas about poetry deserve more attention than criticism has given to them. Particularly, it is very interesting to know who are the poets that Feijoo uses to quote in order to recompose his preferences about poetics. Even more, to methodize the quotations that Feijoo does referred to his favorite writers can offer to us a complete catalogue of his poetic convictions. In this paper, we use bibliometric strategies with the purpose of clearing up what authors Feijoo mentions the most and what does it mean about his aesthetic position.

KEY WORDS

Feijoo, Poetics, Canon.

Recibido: 15 de julio de 2013. Aceptado: 1 de octubre de 2013. 


\section{Introducción}

Los nueve tomos del Teatro crítico universal (1726-1740) y los cinco de Cartas eruditas y curiosas (1742-1760) de Benito Jerónimo Feijoo (1676-1764) albergan en su seno una suerte de tratado de poética, uno de los primeros, si no el primero, de su siglo, que está todavía por estudiar de forma sistemática. Aquí y allá, a lo largo de diferentes cartas y tratados, Feijoo disemina numerosas apreciaciones y comentarios referidos a la poesía de su tiempo, a las grandes obras de los siglos pasados y a lo que él entiende que verdaderamente puede ser considerado y definido como poesía, siempre con vistas, en su caso, a proponer un nuevo paradigma, disgustado como estaba con la poesía de sus contemporáneos. Como ha apreciado repetidas veces Russell P. Sebold ${ }^{1}$, sin duda uno de los estudiosos que más atención ha dedicado al Feijoo preceptista lírico, en las consideraciones sobre poética del benedictino empieza a fraguarse el Neoclasicismo, en tanto abandera con su obra crítica una vuelta a los modelos poéticos de los siglos áureos de la literatura latina y a lo más granado de los Siglos de Oro españoles. De ahí la afirmación de Alberto Blecua, quien explica que «en España comienza con Feijoo y Mayans, como es sabido, una vuelta a los modelos literarios españoles del siglo XVI o de aquellos autores del XVII que mantenían determinadas actitudes clasicistas ${ }^{2} »$.

La poética de Feijoo no es exhaustiva ni completa, a diferencia de la Poética de Luzán, referencia de la primera mitad de siglo, por lo que debe reconstruirse parcialmente a partir de diversas alusiones en numerosos discursos y diferentes cartas de muy variada temática — a falta aún de una edición de su epistolario privado, donde es de creer que podrán encontrarse más reflexiones sobre el asunto-.

1 En muchos trabajos suyos pueden encontrarse alusiones a las ideas poéticas de Feijoo; con todo, las citaremos mayoritariamente por el que acaso sea su libro más importante sobre la poética dieciochesca, en el que actualiza y refunde sus múltiples trabajos anteriores sobre el tema. Nos referimos a Russell P. SEBOLD, Lírica y poética en España, 1536-1870, Madrid, Cátedra, 2003.

2 Alberto BlecuA, «El concepto de Siglo de Oro», en Leonardo Romero Tobar (ed.), Historia literaria / Historia de la Literatura, Zaragoza, Prensas Universitarias de Zaragoza, 2004, págs. 115-160; la cita en pág. 117. 
Con vistas a examinar y reconstruir las ideas poéticas de Feijoo hemos sometido la obra en prosa del benedictino a un proceso de revisión y lectura sistemáticas, con el fin de conformar un corpus con los centenares de alusiones que Feijoo hace en su obra ensayística a poetas y nociones poéticas. Ello ha incluido la aplicación de técnicas bibliométricas que nos han permitido gestionar la información obtenida con vistas a determinar qué autores cita Feijoo, para analizar a partir de esta base por qué lo hace y con qué sentido y concluir cómo transparenta sus ideas poéticas el manejo que Feijoo hace de sus fuentes. La información recogida y expuesta en diferentes gráficas ha sido después valorada y matizada, pues el examen cuantitativo no llega a bastarse por sí solo para determinar las ideas poéticas de Feijoo. Por poner dos ejemplos de esto: no es representativo para conocer sus opiniones literarias el hecho de que Feijoo cite medio millar de veces a Aristóteles a lo largo de su obra ensayística, porque en realidad solo alude una vez a la Poética del estagirita y el resto de alusiones a Aristóteles se hacen en el marco de discusiones filosóficas, teológicas o físicas, entre otra miríada de asuntos; por su parte, Francisco Bernaldo de Quirós es un poeta al que Feijoo alude solo dos veces, pero demuestra tal entusiasmo en sus juicios sobre él que hemos de considerar su figura, dentro de la poética feijoniana, mucho más relevante de lo que esas dos menciones parecen indicarnos. No debemos perder de vista que Feijoo comienza a hablar de poesía en el tomo primero del Teatro crítico universal (1726), en cuyo decimosexto discurso Feijoo ataca con violencia la poesía tardobarroca, y seguirá hablando de poesía en el quinto y último tomo de las Cartas eruditas y curiosas (1760), en cuya vigésimo primera carta vuelve sobre el conocido «Pleito de Lucano» y al hilo de la diatriba define qué entiende por poesía. Treinta y cuatro años de labor crítica se reparten en total a lo largo de las miles de páginas de prosa ensayística feijoniana.

Digamos desde ya que la gran mayoría de alusiones poéticas de Feijoo aparecen segmentadas por doquier a lo largo de su obra; generalmente, al hilo de un tema determinado, Feijoo recuerda algunos versos y los cita, muchas veces añadiendo algún comentario personal. En ocasiones, Feijoo reproduce los fragmentos líricos sin identificarlos con precisión; otras veces, indica escrupulosamente el lugar de donde los toma. En nuestra opinión, aunque tampoco pueda ello elevarse a ley general, seguramente en el primer caso Feijoo recuerda con precisión los versos y no le es necesario comprobarlos; cuando ofrece más datos de los textos que cita quizá se deba a que se ha visto en la obligación de consultarlos. Para probar el hecho de que conoce muchos versos de memoria, podemos recordar el momento en que para desenmascarar a una falsa hechizada repentiza solemnemente el recitado de algunos poemas latinos: «Empecé, pues, 
mis singulares conjuros, que consistían, al modo de los que practicó el Obispo de Angers con Marta Brosier, en versos de Virgilio, Ovidio, Claudiano y otros poetas, articulados con gesto ponderativo y voz vehemente, para que hiciesen más fuerte impresión» (TCU, VIII, VI, § VII, 30; 1739)³.

Decíamos un poco más arriba que Feijoo suele acompañar los fragmentos que cita con algún comentario personal; es en el curso de esos comentarios cuando surgen diferentes valoraciones y apreciaciones poéticas, insertadas a veces en el seno de discursos dedicados a asuntos muy alejados de la poesía propiamente dicha, como, por ejemplo, cuando hablando de la necesidad de que las lenguas puedan enriquecer su léxico, aduce Feijoo un ejemplo poético, tomado de una versión francesa de Virgilio, en el que el traductor se sirve de un neologismo, circunstancia que Feijoo aprovecha para introducir de paso su opinión acerca de la legitimidad de los poetas para acuñar nuevas palabras con vistas a lograr ciertos efectos expresivos ${ }^{4}$.

Sentadas estas bases, podemos ver cómo concreta Feijoo sus preferencias poéticas revisando cuantas alusiones a poemas o poetas en concreto hace a lo largo de su obra ensayística. Seguiremos en nuestro proceder el modelo utilizado por Russell P. Sebold en su análisis de las referencias literarias empleadas por Luzán en su Poética ${ }^{5}$, con ánimo de ofrecer una información minuciosa.

3 Siempre que citamos un fragmento feijoniano, indicamos su título abreviado (TCU para Teatro crítico universal; CEC para Cartas eruditas y curiosas; IA para Ilustración apologética; y JR para Justa repulsa de inicuas acusaciones), y después el volumen, el número de carta o discurso, el parágrafo, si lo hubiera, indicado por el signo §, el número de párrafo, y, tras punto y coma, el año de la primera edición del tomo referido. Citamos siempre por la edición de las obras completas de Feijoo impresas por Blas Román en Madrid en 1781. Por último, modernizamos en cada caso ortografía y puntuación.

4 «[No] es menester para justificar la introducción de una voz nueva la falta absoluta de otra que signifique lo mismo; basta que la nueva tenga o más propiedad o más hermosura o más energía. Mr. de Segrais, de la Academia Francesa, que tradujo la Eneida en verso de su idioma nativo, y es la mejor traducción de Virgilio que pareció hasta ahora, llegando a aquel pasaje en que el poeta, refiriendo los motivos del enojo de Juno contra los troyanos, señala por una de ellas el profundo dolor de haber Paris preferido a su hermosura la de Venus: Manet alta mente repostum / Iudicium Paridis, spretaeque iniuria formae [Eneida, I, vv. 27-28: En el fondo de su alma clavado / sigue el juicio de Paris y la ofensa de despreciar su belleza]; trasladó el último hemistiquio de este modo: Sa beautè meprisèe, impardonable injure [En realidad, la traducción de la Eneida de Segrais dice (I, v. 42): sa beauté meprisée, impardonable outrage; su belleza despreciada, imperdonable ultraje]. Repararon los críticos en la voz impardonable, nueva en el idioma francés; y hubo muchos que por este capítulo la reprobaron, imponiéndole su inutilidad, respecto de haber en el francés la voz irremisible, que significa lo mismo. No obstante lo cual, los más y mejores críticos estuvieron a favor de ella por conocer que la voz impardonable, colocada allí, exprime con mucha mayor fuerza la cólera de Juno y el concepto que hacía de la gravedad de la ofensa que la voz irremisible. Y ya hoy aquella voz que inventó Mr. de Segrais es usada entre los franceses» (CEC, I, XXXIII, 15; 1742).

5 Russell P. SEвоLd, «Análisis estadístico de las ideas poéticas de Luzán: sus orígenes y su naturaleza» (1967), en El rapto de la mente, Barcelona, Anthropos, 1989, págs. 98-128. 
A diferencia de otras poéticas de su momento, pero al igual que Luzán, Feijoo cita mucho más a menudo a los poetas clásicos, sobremanera a los latinos, que a los poetas españoles generalmente más y mejor conocidos en el siglo XVIII. Sus lecturas poéticas caen incuestionablemente del lado de los grandes poetas latinos, y por eso, en su caso, los modelos poéticos en los que concreta su ideal estético responden a la poesía producida en el siglo áureo de la poesía latina o siglo de Augusto (S. I a. C.), cuando, dice, la poesía llegó a «aquel estado de propiedad, hermosura, gala y energía natural en que consiste su verdadera perfección» (TCU, I, XIV, § 6, 25; 1726). Sucedió, no obstante, que

[...] quisieron refinarlas los que sucedieron a aquel siglo, introduciendo adornos impropios y violentos, conque las precipitaron de la naturalidad a la afectación; y de aquí cayeron después a la barbarie. [...] Bien satisfechos estaban los poetas que sucedieron a Virgilio [...] de que daban nuevos realces a los dos artes; pero lo que hicieron se lo dijo bien claro a los oradores el agudo Petronio, haciéndoles cargo de su ridícula y pomposa afectación: Vos primi omnium eloquentium perdidistis [Satiricón, 2: Vosotros, primero de todos, arruinasteis la elocuencia $\left.{ }^{6}\right]$ (TCU, I, XIV, § 6, 25; 1726).

Conviene subrayar la importancia de esta cita, pues Feijoo se está refiriendo a la decadencia de la poesía latina no menos que a la de la española; no pueden leerse estas palabras en 1726 sin pensar de inmediato en la poesía barroca contemporánea, cuyos excesos nunca dejó de condenar Feijoo, partidario como era de la naturalidad como insustituible cualidad del verso.

Volviendo a lo que ahora nos ocupa, los poetas griegos clásicos son también transitados por Feijoo, pero él mismo confiesa leerlos en traducciones latinas porque no conoce la lengua helena (CEC, V, XXIII, 1; 1760). No son desusadas a lo largo de su obra, con todo, las alusiones a diversos poetas griegos, concretamente a Píndaro, considerado «Príncipe de los poetas clásicos ${ }^{7}$ y $\mathrm{Safo}^{8}$, quien

$6 \quad$ Las traducciones serán siempre nuestras a menos que se indique lo contrario.

7 Píndaro es citado como ilustrísimo poeta en TCU, I, § IX, I, 2; 1726, juicio que se apuntala en TCU I, XVI, § XIII, 98; 1726, donde se le considera «Príncipe de los poetas clásicos». Todavía incide de nuevo Feijoo en esta opinión en CEC, V, XXIII, 10: 1760, cuando anota que «Horacio, que lo sabía, siendo el mayor poeta lírico de los latinos, reconocía mucho más alto vuelo en las Odas de Píndaro que en las suyas». Finalmente, Feijoo recuerda en CEC, IV, XIII, 3 ; 1753 los grandes duelos líricos que Píndaro mantuvo con la joven Corina, de Beocia, poeta que llegó a disputarle el «principado de los poetas líricos».

8 Repetidas veces alude Feijoo al supuesto suicidio de Safo (TCU, VII, XVI, Disertación sobre el salto de Leucadia, § VIII, 17-20; 1736), y, así, relata: «que la insigne poetisa Safo fue de un temperamento extre- 
interesó particularmente a Feijoo en su doble condición de mujer y poeta, por lo que no la olvida en su recuento de personajes célebres que ya gozaron la gloria en vida (TCU, VI, I, Paradoja 12, 119; 1734) ni pierde la oportunidad de anotar su gran trascendencia (TCU, VII, XVI; 1736). Finalmente, Feijoo también presto atención a Licofrón y Estesícoro?.

Sin duda, fue Homero quien más le interesó, y parece claro que lo leyó a conciencia a través de alguna versión latina o francesa, toda vez que es más que probable que a los otros poetas helenos mencionados los conociera mucho más fragmentariamente. Sabemos que en la biblioteca del Monasterio de San Vicente tuvo a su disposición Feijoo una traducción al latín de los dos grandes poemas homéricos ${ }^{10}$, y la obra ensayística del benedictino atestigua lo frecuentemente que debió de consultarla. Homero, ciertamente, es contemplado por Feijoo de manera ambivalente: por un lado, no puede evitar reconocer su excelencia poética; y, por otro, no deja de encontrar en su obra ingredientes que reprocharle. Así, Feijoo pone en duda varias de las descripciones de los héroes homéricos (TCU, I, XII. § VII, 28; 1726), lo considera poco fiable como historiador (TCU, II, V, $\S I V, 11 ; 1727$ ) y como naturalista ${ }^{11}$, alude a las falsas deidades a las que se refirió (TCU, V, VIII, § VII, 39; 1733) o discute diferentes asuntos relativos a la caracterización de Ulises $^{12}$ y Penélope $^{13}$, sin perder de vista que

madamente amoroso; que se hizo tan infame por su vida impúdica como famosa por su delicado ingenio; que fue amante y un tiempo amada de Faon; que éste, después fastidiado de ella, se ausentó de Lesbos, de donde eran naturales uno y otro, a Sicilia, por no perder sus importunidades; que ella, impelida del impuro fuego en que ardía, le siguió a Sicilia, pero sólo para experimentar nuevos desdenes: todo esto se lee en varios autores antiguos. Pero que, agitada siempre del amatorio furor, se resolviese a buscar remedio a él, precipitándose de la eminencia del promontorio de Leucadia, sólo se halla en una comedia de Menandro, de que conservó Estrabón un fragmento, donde se lee esta aventura».

9 Licofrón es citado por Feijoo en TCU, IV, VIII, § XVIII, 51; 1730; Estesícoro, mencionado en TCU, I, IX, § I, 2; 1726.

10 Agustín Hevia Ballina, «La biblioteca clásica del Padre Feijoo», II Simposio sobre el Padre Feijoo y su siglo, Oviedo, Centro de Estudios del siglo XVIII, 1981, vol. I, págs. 375-392; el dato en pág. 385, n. 34.

11 Intrigó mucho a Feijoo una planta mágica llamada Nephentes que Homero menciona y que sirve nada menos que para desterrar la melancolía; a lo que se debía que Helena la tomase habitualmente. La inexistencia de tal planta es utilizada como reivindicación de la no ficción en el poema: «la dificultad está en que no se encuentra hoy planta alguna de virtud tan valiente; y la dificultad es bien leve, porque si mienten tanto en esta materia los médicos y naturalistas, ¿que harán los poetas?» (TCU, I, XII, § IX, 37; 1726). El mismo tema reaparece en TCU, VI, IV, § X, 48; 1734.

12 Considera Feijoo que en alguna ocasión Homero hizo a Ulises conducirse de modo excesivamente sentimental: «juzgo que el divino Homero se humanó demasiado cuando pintó a Ulises, entre los regalos de Pheácia, anhelando ver el humo que se levantaba sobre los montes de su Patria Itháca: Exoptans oculis surgentem cerniere fumum / Natalis terrae [Odisea, I, vv. 57-58: [Odiseo] está deseoso de ver cómo el humo se eleva en su tierra natal"]. Es muy pueril esta ternura para el más sabio de los griego.» (TCU, III, X, § VII, 34; 1729).

13 En lo que a Penélope concierne, pone en entredicho Feijoo su proverbial fidelidad, y explica: «Penélope, mujer de Ulises, logró la dicha de que hoy nadie le dispute la honestidad por que tanto la celebran. Mas no fue así en otro tiempo. Francisco Florido Sabino dice que no menos fue ficción de Homero pintar casta 
incluso recuerda los hábitos poco recogidos de Homero, pues, como para Feijoo prueba aquel verso de Horacio, «Laudibus arguitur vini vinosus Homerus. [Epístolas, I, 19, v. 6: De bebedor se acusa a Homero por su elogio del vino]», era el inmortal rapsodo demasiado amigo de la bebida (CEC, V, XXV, 6; 1760). Ahora bien, pese a todo, Feijoo no duda en apropiarse del elogio que Veleyo Paterculo hizo «de Homero: Neque ante illum, quem imitaretur, neque post illum, qui eum imitari posset inventus est.» [Compendio de Historia Romana, I, 5: Antes que él no había encontrado ningún ejemplo que imitar, ni entre sus sucesores ninguno que pudiera imitarlo] (TCU, IV, XIV, § XIV, 37; 1734).

Desde un prisma más puramente poético, Feijoo alude a varios de sus más logrados versos, en especial a las fórmulas homéricas; en concreto, a los delicados brazos de Hera, comúnmente aludida en la Ilíada como «Hera, la de los hermosos brazos» (CEC, I, XLII, 3; 1742), y a la definición homérica de la aurora, que Feijoo parafrasea: «dice Homero que la Aurora es hija del Aire, [se encarga] de guardar las puertas del Oriente y abrirlas cada mañana con sus dedos de rosas, enviando delante los céfiros para disipar las sombras» (CEC, I, XLII, 3; 1742). Además, Feijoo reconoce la utilidad de Homero a la hora de fomentar la unidad del ejército, luego admite que sus poemas encubren enseñanzas valiosas (TCU, IV, XIV, § XV, 39, Adición 12; 1740), consecuentemente lo considera superior a Virgilio (TCU, I, XVI, § XVII, 124; 1726 y CEC, V, XXV, 10; 1753), y, en definitiva, lo encumbra a la categoría de poeta supremo, pues hay unanimidad absoluta acerca de su talento incomparable (CEC, III, XXIX, 2; 1749).

Anacreonte, por último, tan importante a lo largo del siglo, sobre todo en lo relacionado con la poesía rococó, no interesó particularmente a Feijoo: alude a él en calidad de importante poeta clásico (TCU, IV, XV, Adición, 109; 1740), pero también subraya sus hábitos poco edificantes: «Anacreón [...] a lo venéreo agregó lo intemperante, como evidencian algunos fragmentos suyos que he visto traducidos en prosa francesa y en los cuales descubre que apenas apartaba jamás de sí la botella» (CEC, V, XXIII, 11; 1750), convirtiéndolo en una suerte de referente del poeta de vida disipada.

Dejando a un lado, pues, a los poetas griegos, y dando un salto a la península itálica, es de rigor advertir que son sin duda los poetas del círculo de Mecenas los que para Feijoo encarnan el ideal máximo de poesía, a saber: Virgilio, Ovidio y Horacio, sobremanera; Propercio, Tibulo y Catulo, en menor medida; y luego, los grandes satíricos, especialmente Juvenal, sin perder tampoco de vista

a Penélope que de Virgilio representar lasciva a Dido. Cita contra la pretendida honestidad de Penélope al poeta Licofrón y al historiador Duris de Samos. Este segundo describe en Penélope una vilísima prostituta. Tomás Dempstero añade al mismo intento otro antiguo historiador llamado Lisandro, el cual dice lo mismo que Duris de Samos» (TCU, IV, VIII, § XVIII, 51; 1730). 


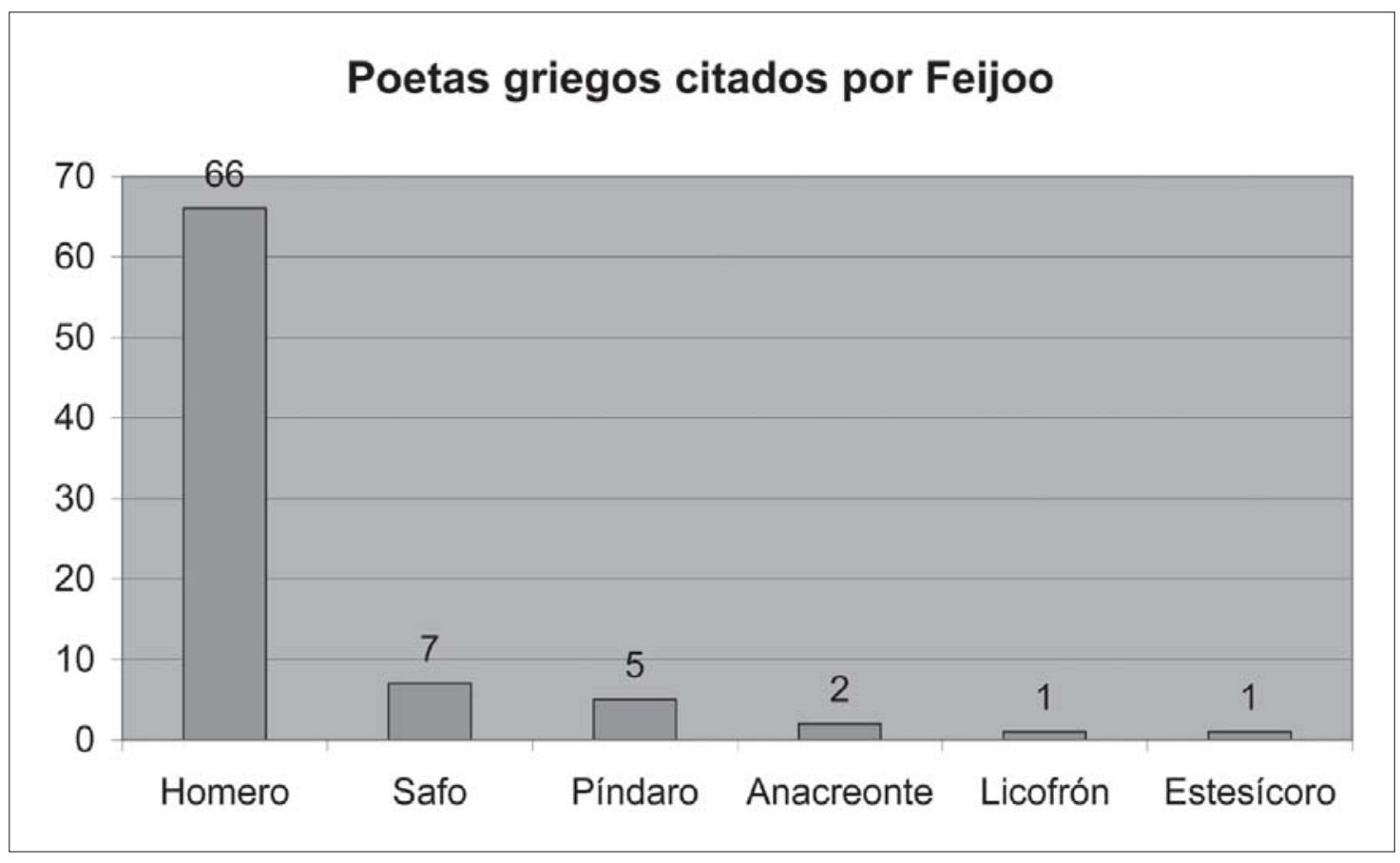

a poetas ligeramente posteriores como Lucano, otra de sus devociones, Marcial, muy querido por Feijoo, o Estacio, Ausonio y Claudiano, pero también Manilio y Lucrecio $^{14}$.

De nuevo, las lecturas feijonianas pueden explicarse mejor a la luz del catálogo de la biblioteca del monasterio de San Vicente. En primer lugar hay que notar que Virgilio y Ovidio, dos de los poetas más citados por Feijoo, eran objeto de estudio corriente en la época; ello aclara también por qué a menudo Feijoo no indica con exactitud la procedencia de los versos que reproduce, pues en buena parte de esas ocasiones a buen seguro está citando de memoria. Él mismo nos confiesa atesorar una antología de epigramas de Marcial, a lo que debe añadirse que tenemos constancia de que dispuso, en la biblioteca del Monasterio de San Vicente, de unas Opera Omnia cum commentarïs de Virgilio y

14 Es importante subrayar que este canon feijoniano responde al propuesto por otros autores de su tiempo. Gregorio Mayans y Siscar en su Oración en alabanza de las elocuentísimas obras de Don Diego Saavedra Fajardo (1725) cita a los siguientes poetas latinos, como se ha ocupado de estudiar Fraçois LoPEZ («Mayans y sus poetas», en Actas del Congreso Internacional sobre Gregorio Mayans, Oliva, Ayuntamiento de Oliva, 1999, págs. 251-264): Catulo, Horacio, Virgilio, Tibulo, Propercio, Ovidio, Persio, Marcial y Juvenal. Gaspar Melchor de Jovellanos, por su parte, citará años después entre sus poetas latinos predilectos, a Horacio, Virgilio, Ovidio, Tibulo, Lucano y Juvenal (Juan Antonio López Férez, «Alusiones a autores griegos o latinos en algunas obras de Jovellanos», en Jovellanos, el valor de la razón, ed. de Ignacio Fernández Sarasola, Elena de Lorenzo Álvarez, Joaquín Ocampo Suárez-Valdés y Álvaro Ruiz de la Peña Solar, Gijón, Instituto Feijoo de Estudios del Siglo XVIII, 2011, págs. 587-602; puede leerse una versión extendida de este texto en Minerva, 24 (2011), págs. 209-238). 


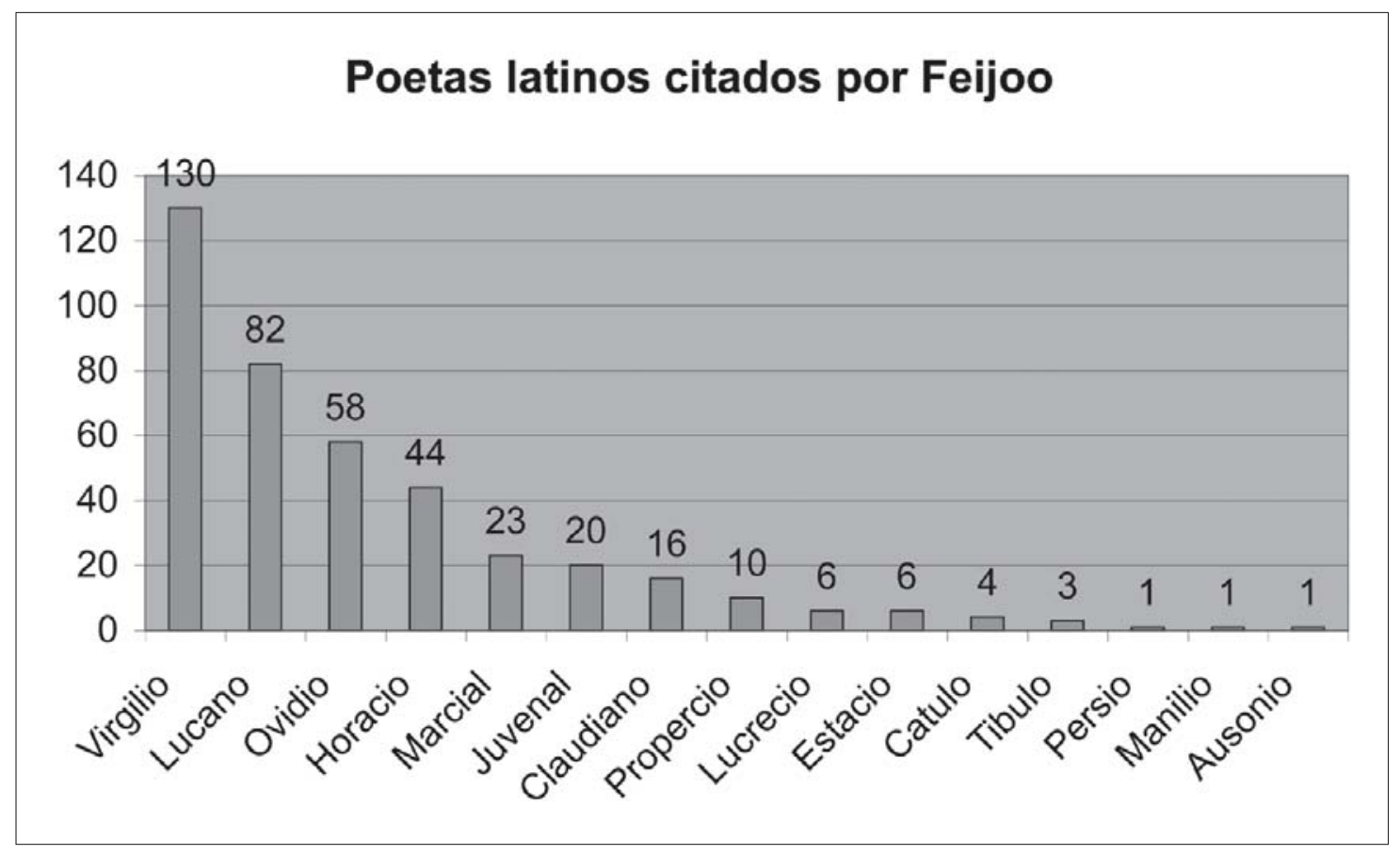

otras de Ovidio; además, de la lectura de los textos feijonianos cabe deducir que Feijoo hubo de manejar alguna edición de la Farsalia de Lucano, sin perder de vista algún otro florilegio, al uso de los Poetarum Classicorum (cuya edición de Venecia de 1715 se ha dicho que poseyó).

Siendo más detallados, lo cierto es que Virgilio, Lucano, Ovidio y Horacio, por este orden, son los poetas que Feijoo más cita, y se conoce en que son los que más lee: de esta guisa, el de Casdemiro aduce sus testimonios en muy variopintas situaciones y al hilo de diversas materias ${ }^{15}$. Marcial, por su parte, emparentado

15 En los discursos relacionados con el amor son muy frecuentes las citas de los poetas elegíacos latinos, especialmente Ovidio, y, en menor grado, Propercio — Feijoo da cuenta, por ejemplo, de la situación de Propercio con respecto de Cynthia, y las infructuosas estrategias que siguió para liberarse del amor terrible que por ella sentía, fundamentalmente la de apartarse de ella; Feijoo nos relata que «si la pasión fuere muy fuerte y el corazón también lo fuere, hay poco que fiar de este expediente [alejarse del ser amado]. Apártase el cuerpo y se queda el alma o aunque se vaya el alma va con ella el amor: por eso oportunamente comparó el gran poeta un corazón penetrado de la pasión amorosa a la cierva herida, que por más que huya lleva siempre clavada la flecha que le disparó el cazador: Haeret lateri laetatis arundo [Eneida, IV, v. 73: sin poder sacudir de sí la mortal saeta]. Propercio, aunque tan decisivamente recomendó la ausencia por eficacísimo remedio del amor, parece que usó de ella sin que le sirviese de cosa. Él, por lo menos, en el lugar mismo que alegamos arriba, habla de su viaje a Atenas como cosa ya resuelta, y emprendida a este fin: Magnum iter, ad doctas proficisci cogor Athenas, / ut me longa gravi solvat Amore via [Elegías, III, 21, vv. 1-2: Se me obliga a emprender viaje a la docta Atenas / para que el largo trayecto me absuelva del amor]. Si ejecutó el viaje, no le aprovechó el remedio, pues en el libro 4 de sus Elegías vemos una en que habla de Cynthia, ya muerta, con expresiones que le declaran aún apasionado. Ni se piense que Cynthia era una hermosura puramente ideal o fingida para dar materia a versos amatorios. Fue mentido el nombre, no el sujeto. Su verdadero nombre fue Hostilia, según dice Apuleyo: y Propercio, que ardía por ella, la sacó en sus poesías disfrazada con el nombre de Cynthia, 
como está con Quevedo, quien por cierto lo tradujo, es quizá el poeta que más influyera en los versos de Feijoo, entre los que abundan los epigramas y los ataques a poetas rivales; por parecido motivo, Persio también pudo haberle interesado, pero sin embargo no goza de mucho predicamento en la obra feijoniana ${ }^{16}$, pues parece claro que de los dos grandes satíricos el de Volterra interesó a Feijoo mucho menos que Juvenal. Propercio ${ }^{17}$, Tibulo $^{18}$, Catulo ${ }^{19}$ y Claudiano ${ }^{20}$ son por su parte aducidos con alguna frecuencia, pero en cualquier caso menor en comparación con los poetas a los que acabamos de referirnos. Mientras Estacio ${ }^{21}$ y Ausonio $^{22}$ los siguen aún a más distancia, los dos poetas sin fábula por excelencia, Manilio $^{23}$ y, en particular, Lucrecio ${ }^{24}$, son objeto de cierta atención.

por ocultar el objeto de su pasión» (TCU, VII, XVI, § IV, 13 y 14; 1736)—. Vicente Cristóbal ha estudiado la influencia de Ovidio en los discursos de Feijoo «Causas de amor» y «Remedios de amor» (TCU, VII, XV y XVI, respectivamente; 1736): Vicente Cristóbal, «Los Remedia Amoris de Ovidio en la visión crítica del P. Feijoo», Cuadernos de Filología Clásica (Estudios latinos), Universidad Complutense, 1991, págs. 233-239. Debemos aclarar, no obstante, que la lectura que Feijoo hace y propone de Ovidio en estos dos discursos es puramente científica, de modo que no entra en asuntos de valoración poética o literaria.

16 Persio es solo citado en una ocasión, como ejemplo de poeta que no necesitó de la fábula en sus poemas, en CEC, III, V, 7; 1750.

17 Obviando la información ofrecida en la nota 15, Propercio es nombrado como ilustre poeta (TCU, IV, XIV, § XXII, 77, Adición, 2; 1740) y se anota que gozaría la misma gloria de Horacio, Virgilio y Homero si «la lasciva impureza de sus expresiones no empañara el tersísimo lustre de sus versos» (TCU, IV, VIII, § I, $2 ; 1730)$.

18 Tibulo es citado como gran autor latino (TCU, IV, XIV, § XXII, 77, Adición, 2; 1740), se reproducen unos versos de su elegía I, 8 dedicados a la importancia que para los egipcios tenía la agricultura (TCU, VIII, XII, $\S 6,17$; 1739) y también es aducido como fuente a la hora de caracterizar a los hispanos, a quienes llama «atrevidos» (TCU, IV, XIII, § 2, 6; 1730).

19 Considera Feijoo que Catulo es un poeta excesivamente irreverente y lascivo, aunque, no obstante, dice de él que lo salva «el primor del verso» (TCU, IV, XI, § 2, 3; 1730). Del mismo modo que con Propercio, Feijoo considera que si no fuera por sus excesos, sería Catulo elevado a la altura de Virgilio u Horacio (TCU, IV, VIII, § I, 2; 1730); no obstante, Feijoo saluda a Catulo como ejemplo de exquisito poeta (TCU, IV, VIII, § I, 2; 1730 y TCU, IV, XIV, § XXII, 77, Adición, 2; 1740).

20 Claudiano, el gran poeta de Alejandría que viviera a caballo entre los siglos IV y v, es convocado por Feijoo con bastante frecuencia. Es citado como ejemplo de estilo sublime (TCU, IV, VIII, § V, 13) y como gran autor latino (TCU, IV, XIV, § XXII, 77, Adición, 2; 1740), y sus versos son aducidos recurrentemente por Feijoo, ya para describir el vértigo de una caída (TCU, I, IV, § V, 19; 1726), definir el espíritu de los hombres sabios —que compara con la cumbre de Olimpo, nunca inquietada por las tempestades por su posición superior a las nubes y a los vientos (TCU, II, I, § I, 1; 1728)—, describir la generosidad (TCU, VI, I, Paradoja nona, 84; 1734), caracterizar a una mujer (TCU, VI, II, § VI, 58; 1734) o definir a las sirenas (TCU, VI, VII, § VIII, 41; 1734), sin perder de vista la larga paráfrasis que Feijoo hace de un pasaje de uno de sus poema, en que se narra el descenso al Infierno de Ulises (TCU, VII, VI, § IX, 35; 1736).

${ }^{21}$ Aparte de su aparición como autoridad en el Pleito de Lucano, ya atendido, se le menciona sin demasiada trascendencia, como en TCU, IV, XIV, § XXII, 77, Adicción, 2; 1740.

22 Ausonio solamente es citado en TCU, VIII, X, Paradoja XVIII, 138; 1739.

23 Manilio es aludido por Feijoo en TCU, IV, XII, § XVI, 40; 1730.

24 Su poesía es ponderada en CEC, III, V, 7; 1750, como lo había sido ya en CEC, I, XXXIII, 6; 1742 , donde se da cuenta de su gran capacidad para introducir helenismos cuando es necesario hacerlo. Por último, se recogen las circunstancias de su fulminante suicidio, inducido por un filtro amoroso envenenado: «Eusebio 
Deteniéndonos ahora en los poetas más aludidos por Feijoo, no cabe duda de que Virgilio, Lucano, Ovidio, Horacio, Marcial y Juvenal fueron los que durante más gratas horas de lectura hubieron de acompañarlo.

\section{Virgilio, «que sacaba oro del informe o rudo plomo»}

Aunque Feijoo atacó con dureza los excesos ficcionales de la Eneida, son numerosísimas las referencias que hace de los versos virgilianos. El de Mantua goza sin discusión de un lugar preeminente en la poética feijoniana, pues es el poeta al que más veces se refiere y cuya gran calidad no discute, si bien es cierto, y sobradamente sabido, que Lucano era el poeta favorito de Feijoo. Por supuesto, Feijoo se vale de Virgilio como fuente geográfica (TCU, VII, IV, § VIII, 38; 1736) o antropológica (TCU, VIII, XII, $\S$ X, 41; 1739) — mucho atrajo a Feijoo el valor testimonial de la poesía-, pero nos interesa mucho más recordar que de Virgilio dice Feijoo que fue cima de la literatura (TCU, I, XIV, § VI, 25; 1726), y en especial de la épica (TCU, I, XV, § VI, 31; 1726), que fue sublime su estilo (TCU, IV, VIII, $\S \mathrm{V}, 13 ; 1734$ ) y que sin lugar a dudas fue un gran poeta (TCU, IV, VIII, § I, 2; 1734). Prueba fehaciente del respeto que sentía por el mantuano es la afirmación de que: «su majestad heroica me enamora; su grandilocuencia poética me hechiza; aquellos sonoros y soberanos golpes, que a trechos deja caer como desde la cumbre del Olimpo sobre la mente del que lee, totalmente me arrebatan» (TCU, IV, § XIV, 42; 1734). Además, Virgilio es citado cuando Feijoo se refiere al que entiende como uno de los constitutivos esenciales de la poesía: la musicalidad ${ }^{25}$. Del mismo modo, pondera las cualidades técnicas de Virgilio, cristalizadas en su talento para inventar palabras, don este que según Feijoo no puede adquirirse por estudio, sino por puro numen ${ }^{26}$; parecidamente, Virgilio

refiere que al poeta Lucrecio sucedió la misma desventura; porque Lucila, su mujer, creyéndole tibio y aun sospechándole infiel, con un filtro quiso asegurar su buena correspondencia; el cual le enfureció de modo que se quitó la vida» (TCU, VII, XV, § XIV, 67, Adición, 8; 1740).

25 «La poesía no puede prescindir de la versificación; mas como el entusiasmo también es algo admisible en la oratoria, en la esencia de la poesía al entusiasmo debe agregarse como parcial constitutivo de ella la versificación. [...] [Los poetas] frecuentemente dan el nombre de canto y música a la poesía. Virgilio: Sicelides Musae paulo moiora canamus [Bucólicas, IV, v. 1: Musas de Sicilia, elevemos un poco nuestros cantos]. El mismo: Arma, virumque cano [Eneida, I, v. 1: Canto las armas y al héroe]. Horacio: Musa lyrae solers et cantor Apollo [Epístola a los Pisones, v. 407: la Musa hábil con la lira y el cantor Apolo]. Es así que la poesía es cierta especie de música, cuya modulación se representa en la artificiosa colocación de palabras y sílabas, como la de la música ordinaria en la ordenada positura de las notas; y nada de esto hay en la prosa» (CEC, V, XXI, 17; 1760).

26 «Es a la verdad para muy pocos el inventar voces o connaturalizar las extranjeras. Generalmente, la elección de aquellas que colocadas en el periodo tienen o más hermosura o más energía pide numen especial, 
también es visto por Feijoo como ejemplo de la emoción que la gran poesía puede desencadenar en los lectores ${ }^{27}$, como ejemplo de gran escritor capaz de mejorar las fuentes de las que se surte ${ }^{28}$ y como poeta de enorme poder sugestivo, que logra con unas pocas pinceladas insinuar una realidad o un sentimiento mucho más profundos ${ }^{29}$.

Es cierto que algún lunarcillo tiene también la relación de Feijoo con el mantuano, pues en más de una ocasión subrayó sus defectos ${ }^{30}$ : lo consideró in-

el cual no se adquiere con preceptos o reglas. Es dote puramente natural; y el que no la tuviere, nunca será ni gran orador ni gran poeta. Esta prenda es quien, a mi parecer, constituye la mayor excelencia de la Eneida. En virtud de ella, daba Virgilio a la colocación de las voces, cuando era oportuno, aquel gran sonido con que se imprime en el entendimiento, o en la imaginación, una idea vivísima del objeto. Tal es aquel pasaje: Necdum etiam causae irarum, saevique dolores / Exciderant animo; manet alta mente repostum / Iudicium Paridis, spretaque iniuria formae [Eneida, I, vv. 29-31: No había olvidado las causas de su ira / ni su amargo dolor. Queda en lo hondo de su ánimo clavado el juicio de Paris / y el injusto desprecio de sus hermosas formas]. Dentro de pocas voces, iqué pintura tan viva, tan hermosa, tan expresiva, tan valiente de la irritación de la diosa y de la profunda impresión que había hecho en su ánimo la injuria de anteponer a la suya otra belleza! Donde es bien advertir que el síncope Repostum es de invención de Virgilio, y no introducido sólo a favor de la libertad poética; sino porque aquella nueva voz, o nueva modificación de la voz Repositum, da más fuerza a la expresión» (CEC, I, XXXIII, 16; 1742).

27 «Elegantísimos son los versos con que Virgilio, en el Libro 6 de la Eneida [Eneida, VI, vv. 855 y siguientes], habla de la muerte del malogrado joven Marcelo. Sin embargo, se refiere que esos versos, leídos por el mismo Virgilio a Augusto y Livia, hicieron llorar aquél y desmayarse ésta» (CE, II, VII, 67; 1745).

28 «De Virgilio se dijo que sacaba oro del informe o rudo plomo de Ennio, u otra materia, que no es menester nombrar ahora, más vil que el plomo y la escoria» (CEC, IV, X, 4; 1753).

29 Refiere Feijoo la determinación de Dido al suicidarse, ensalzando con ello el valor poético de Virgilio: «aunque Virgilio representa a la reina Dido mujer de ánimo heroico y advierte que con grande estudio procuró ocultar en la última hora de su vida la determinación de quitársela, la pinta en aquella extremidad con una insólita fiereza, con un extraño horror, de que resultaba al semblante, a los ojos, a los pasos tan feroz turbación, que más parecía furia que mujer. Ni puede ser otra cosa en quien queda con alguna advertencia para conocer la tragedia a que se prepara: At trepida, \& caeptis immanibus effera Dido / Sanguineam volvens aciem, maculisque trementes / Interfusa genas, \& palida morte futura / Interiora domus irrumpit limina....» [Eneida, IV, vv. 642-645: Mientras, Dido, temblando, arrebatada por su terrible designio, / con los ojos inyectados en sangre y las mejillas trémulas, / pálida por la muerte futura, irrumpe por la puerta en el interior] (TCU, VI, I Paradoja catorce, 151; 1734). En general, el personaje de Dido interesó mucho a Feijoo, a ella se refiere en TCU, IV, VIII, § XVII, 50; 1734; TCU, VI, I Paradoja catorce, 159; 1734 y TCU, VII, XV, § XIII, 60; 1736, siempre destacando la fuerza poética y trágica del personaje.

30 Irritaban a Feijoo algunos aspectos de la Eneida. No le gustaba el enamoramiento de Dido por Eneas, que creía en primer lugar inverosímil y en segundo lugar indecente, pues consideraba imposible que «una reina insigne acreditada de casta condescienda al momento como la más infame prostituta» [Feijoo se refiere al momento en que merced a un ardid de Juno, a causa de una tormenta, Eneas y Dido se encuentran en una cueva y consuman su amor: Eneida, IV, vv. 160-164]; asimismo, Feijoo también aludió a lo que él cree que es un comportamiento indigno de un héroe cuando Eneas da muerte a Turno, quien rendido y desarmado le está pidiendo clemencia [Eneida, XII, vv. 930-952]. Más adelante (TCU, IV, XIV, $\S$ XV, 39, Adición, 6; 1740) Feijoo sumará a estos reproches uno más: la fragilidad de Eneas, de nuevo impropia de un héroe. Para demostrarla, Feijoo recuerda el pasaje en que Eneas, a merced de una gran tormenta, teme, gime y suplica [Eneida, I, vv. 91-92]: « ¿pero no hay también en Virgilio defectos? Pienso que más esenciales; porque desfiguran a su héroe, degradándole de tal. [...] El erudito Carlos Perrault le notó haber pintado un llorón a Eneas. Es así que frecuentemente y sin mucho motivo le hace derramar 
ferior a Homero y a Lucano, como ya recordamos, e incluso afirmó que Virgilio debió parte de su éxito a que «lisonjeó con exceso a los romanos» y a que «el favor de Augusto le ayudó mucho» (TCU, IV, XIV, § XV, 39; 1730). En última instancia, en una operación muy típica en Feijoo, nota ciertas semejanzas entre versos virgilianos y distintos momentos de la Biblia ${ }^{31}$.

\section{Lucano, «el único poeta que no mintió»}

Más allá de la cuantificación de las referencias, Lucano fue a buen seguro el poeta favorito de Feijoo, lo que se percibe en el entusiasmo con que el benedictino alude a muchos de sus versos. De hecho, la primera vez que evoca a Lucano, en el tomo I de su Teatro crítico, Feijoo refiere conmovido un hermoso pasaje de la Farsalia con todo lujo de detalles y rara intensidad dramática, e incluso reproduce un puñado de versos que él mismo traduce:

Lucano, en el Libro 5 de la Guerra Civil, hace una bella digresión sobre la felicidad del pobre barquero Amiclas, cuando pinta a César en el silencio de la noche pulsando la puerta de su choza para que le conduzca prontamente a la Calabria. Todo el mundo está conmovido y temblando con los movimientos de la guerra civil; y dentro de la misma Grecia, que es el teatro de la Guerra, vecino a los mismos ejércitos, duerme, sin temor alguno, un pobre barquero sobre enjutas ovas.

copiosas lágrimas. Otro crítico satisfizo esta acusación, diciendo que Virgilio en las fingidas lágrimas de Eneas tuvo la ingeniosa mira de lisonjear las verdaderas de Augusto, de quien refiere que era de corazón tierno y muy ocasionado al llanto» (TCU, IV, XIV, § XV, 39, Adición, 4; 1740). Feijoo retomará en las Cartas eruditas este tema, aunque con ánimo más apacible: «la Eneida de Virgilio ha sido hasta ahora, y verosímilmente lo será en la posteridad, la admiración del mundo. ¿Y no tiene defectos? Tantos, que conociéndolos su mismo autor había propuesto ir a hacer mansión tres años en Atenas para corregirla; y habiéndole preocupado, antes de ejecutarlo, la enfermedad de que murió, viéndose próximo a la hora fatal, mandó que toda aquella obra se quemase; pero impidió tan lamentable estrago el contrario orden de Augusto» (CEC, IV, XII, 19; 1753).

31 Un verso de Virgilio llama la atención de Feijoo y desata un comentario al respecto: «Et curvae rigidum falces conflantur in ensem [Geórgicas, I, 508: las curvas hoces [del arado] se funden para hacer espadas rígidas]. Este último verso de Virgilio me excita en la idea una ajustadísima contraposición harmónica entre lo que dice este poeta profano y lo que el Espíritu Santo dictó por la pluma del profeta Micheas. Virgilio ponderó como infelicidad grande de aquellos tiempos, el que los instrumentos de la Agricultura se convertían en instrumentos de guerra; esto es, las hoces para segar las mieses, en espadas. Micheas celebra como felicidad insigne de los pueblos, en el dominio pacífico de la ley de Gracia, el que los instrumentos de la guerra se conviertan en instrumentos de agricultura; esto es, las espadas en rejas de arados, y las astas de las lanzas en azadones: Et concident glaudios suos in vomeres \& hastas suas in ligones» [La Profecía de Miqueas, IV, 3: convertirán sus espadas en rejas de arados y sus lanzas en azadones] (TCU, VIII, XII, § VII, 26; 1739). Paralelamente, en CEC, II, VIII, 52; 1745 halla Feijoo indicio de que el ritual eucarístico del Miércoles de Ceniza tiene un próximo precedente en unos versos del Libro 4 de la Geórgicas. 
Despiértanle los golpes que da a su puerta el generoso caudillo, sin introducir en su pecho el menor susto; porque aunque no ignora que está toda la campaña cubierta de tropas, sabe también que no hay en su choza cosa que pueda brindar los militares insultos: O vita tuta facultas / Pauperis, angustique lares! O munera nondum / Intellecta Divum! Quibus hoc contingere templis, / Aut potuit muris, nullo trepidare tumultu / Caesarea pulsante manu?». [Y traduce Feijoo:] «¡Oh vida del pobre (exclama el poeta), que tienes la felicidad de estar exenta de las violencias! ¡Oh pobreza, beneficio grande de los dioses, aunque no reconocida de los hombres! ¿Qué muros o qué templos gozaron el privilegio que tienen Amiclas y su choza de no temblar a los golpes de la robusta mano de César!» [Farsalia, V, vv. 526-530] (TCU, I, III, § IX, 35; 1726).

Es significativo, por cierto, que Feijoo vuelva sobre este episodio (TCU, I, VIII, § IX, 41; 1726) y que con frecuencia recuerde algún pasaje memorable de la Farsalia, reproduciendo los versos a los que se refiere y, por mejor gustarlos, traduciéndolos él mismo ${ }^{32}$.

Pero Lucano es ante todo el protagonista del conocido como «Pleito de Lucano», que ahora solo podremos atender muy superficialmente. Según la historiografía tradicional, el pleito puede resumirse así: en 1730 Feijoo afirmó que prefería a Lucano sobre Virgilio (TCU, IV, XIV, § XV, 39; 1730), preferencia que llevó a Marcelino Menéndez Pelayo a observar que Feijoo, si bien poseía una capacidad racional destacada que hacía válidos sus juicios filosóficos generales, tenía muy mal gusto literario ${ }^{33}$ y que «en el fondo sostenía la causa de Lucano por el hecho de haber sido Lucano español», y todo ello a causa de su incapacidad literaria, pues añade que Feijoo no debía de darse «muy buena cuenta de las razones de arte que hacen que Virgilio sea un poeta perfecto en su línea y enteramente adorable, y Lucano solo un gran poeta de decadencia, monótono y fatigosísimo de leer ${ }^{34} »$. Así, «Feijoo, a despecho de sus aciertos

32 De nuevo Feijoo traduce un pasaje particularmente intenso de la Farsalia: «Lucano, refiriendo la fuga de Catón con sus vencidas tropas por los arenosos desiertos de la Libia, inundados de todo género de serpientes ponzoñosas, dice que llegando el ejército fatigadísimo de sed a una copiosa fuente, única en aquella soledad por donde caminaban, no se atrevían los soldados a beber, porque la vieron circundada de muchas especies de sabandijas venenosas, que en la misma fuente saciaban su sed. A cuyo mal fundado miedo acudió Catón diciéndoles que las bestias ponzoñosas sólo dañaban mordiendo; que aquella agua por consiguiente carecía de toda infección; y arrojándose intrépido a beberla el primero: Ductor, ut aspexit perituros, fonte relicto, / Alloquitur vana specie conterrite lethi, / Ne dubita miles tutos haurire liquores: / Noxia serpentum est admixto sanguine pestis: / Morsu virus habent, \& fatum dente minantur: / Pocula morte carent. Dixit, dubiumque venenum / Hauxit. [Farsalia, IX, vv. 610-616]» (TCU, II, II, § VIII, 51, Adición, 4; 1740).

33 Marcelino Menéndez Pelayo, Historia de las ideas estéticas en España: el siglo XVIII, Santander,

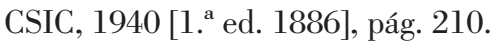

34 Menéndez Pelayo, Historia de las ideas estéticas: el siglo XVIII, pág. 210. 
teóricos, no sentía verdaderamente la poesía» o, más todavía, tenía «un perverso gusto ${ }^{35} »$.

Pero las razones que hicieron que Feijoo declarase su preferencia por Lucano ante Virgilio son bastante más complejas que su nacionalidad, lo que está a su vez muy lejos de significar que Feijoo no tuviese en altísima estima a Virgilio, como ya hemos visto. La clave está en que Feijoo considera que la elaboración de la historia verdadera efectuada por Lucano en la Farsalia es mucho más compleja y provechosa que el uso de la ficción que hace Virgilio; es más, afirma que «sería sin duda una grande infamia de la poesía profesar antipatía irreconciliable con la verdad» (TCU, IV, XIV, § XV, 40; 1730) y que «¡Ojalá todos los poetas heroicos hubieran hecho lo mismo que Lucano! Supiéramos de la antigüedad infinitas cosas que ahora ignoramos y siempre ignoraremos» (TCU, IV, XIV, § XV, $40 ; 1730)$, dado que «lo que yo admiro más en Lucano es que no hubo menester fingir para dar a su poema toda la gracia a que otros poetas no pudieron arribar sin el sainete de las ficciones». Feijoo descree totalmente de que la ficción sea uno de los constitutivos esenciales de la poesía, incluso considera que «bien lejos de ser la ficción de la esencia de la poesía, sin temeridad se puede decir que es corrupción suya» (TCU, IV, XIV, § XV, 39, Adición, 9; 1740). Así, nos recuerda Feijoo que los primeros poetas de que tenemos noticia prescindieron de fábula. Esto es trascendental, porque la poesía sin fábula, explica el benedictino, puede cumplir más eficazmente su cometido último, y de ahí vendrá su prestigio: el que tenían quienes «cantaron instrucciones religiosas, morales y políticas, con que redujeron los hombres de la feroz barbarie en que vivían a una sociedad racional y honesta» (TCU, IV, XIV, § XV, 39, Adición, 9; 1740).

De tal forma, razona Feijoo, como la función de la poesía es la instrucción, y para la instrucción la ficción es superflua, la ficción es prescindible. Para el de Casdemiro, la ficción es la prueba evidente de que la poesía ha abandonado su fin primero, de ahí su desprestigio: «la poesía en su primera instrucción tenía por objeto deleitar instruyendo: mas con el tiempo se dirigió únicamente al deleite, abandonando la instrucción» (TCU, IV, XIV, § XV, 39, Adición, 9; 1740). En relación con todo lo anterior, Feijoo cree que la aparición de la fábula o bien obsta a la instrucción o bien entra en franca contradicción con ella (TCU, IV, XIV, § XV, 39, Adición, 10-13; 1740), todo lo cual es un severo demérito de los poetas. Por eso y no por otra cosa critica Feijoo a la Eneida, pues entiende que Virgilio poco hace por instruir en su poema.

En suma, Feijoo se está limitando a defender la utilidad de la poesía y a abogar por que la poesía cumpla con los requisitos, o reglas, si se quiere, que la

35 Menéndez Pelayo, Historia de las ideas estéticas: el siglo XVIII, pág. 212. 
harán útil. Sobre esta base, finalmente, debemos relativizar el combate, fundamentalmente artificial, entre Virgilio y Lucano (o, como conviene precisar, entre la Eneida y la Farsalia), pues nada tiene que reprocharle Feijoo a las Geórgicas, sino todo lo contrario.

Feijoo dispensa también a Lucano, por supuesto, las referencias más o menos habituales cuando habla de un poeta de su agrado. Lo considera el gran poeta hispano (TCU, IV, XIV, § XV, 38; 1730) y lo utiliza para volver sobre su tan querido menosprecio de corte (TCU, I, IV, § I, 4-5; 1726) y sobre su reivindicación de la agricultura (TCU, VIII, XII, § VII, 25; 1739), sin olvidar mencionar algún suceso prodigioso consignado por Lucano (el hecho de que las estatuas del capitolio sudasen y lloraran como presagio de la guerra civil en TCU, III, VI, $\S$ IX, 49; 1729). Además, siempre tan racionalista, Feijoo descubre algún que otro defecto en su poeta favorito: «Confesaréle a Lucano un defecto de que ya otros le han acusado, que es la prolijidad y amplificación algo tediosa en varias partes del poema [la Farsalia], nacida de que no era dueño del ímpetu que le arrebataba para reprimirle oportunamente» (TCU, IV, XIV, § XV, 39, Adición, 4; 1740). No obstante, claro es, Feijoo se ocupó de encarecer como nadie el estilo de Lucano, de quien afirma que

[...] la valentía de su metro es tanta, que algunos la tachan de nimia. Lilio Giraldo le comparó ya a un caballo indómito y lozano, ya a un soldado robustísimo, pero inconsiderado. Luis Vives dice que es tan vivo en las representaciones, que al describir un combate más parece desahogar su propia cólera en la campaña que pintar la ajena en el gabinete. Por lo que mira a la naturalidad, ¿cómo pueden negársela los que le culpan, como Julio César Scalígero, de que siempre se dejaba arrebatar del fervoroso ímpetu de su genio cuando escribía? De modo que sin pensarlo engrandecen a Lucano los que quieren deprimirle. ¿Quién se puede alejar más de toda afectación que aquel que sigue siempre el impulso del natural? (TCU, IV, XIV, § XV, 41; 1730).

Más tarde añadirá: «Lucano siempre despierto, vivo, ardiente, armonioso, enérgico, sublime, por todo el discurso de su poema se mantiene en aquella elevación donde le vemos colocarse al primer rapto del numen» (TCU, IV, XIV, $\S \mathrm{XV}, 43 ; 1730)$.

Por decirlo en dos palabras, para resumir lo que de Lucano pensaba Feijoo, podemos recordar el por su trascendencia ya citado e infrecuente elogio que le dedicara y que ya sabemos que para el benedictino significaba muchísimo: Lucano fue «el único poeta que no mintió» (TCU, II, II, § VIII, 51, Adición 5; 1740). 
Ovidio fue un poeta que sin lugar a dudas excitó también el interés de Feijoo. De hecho, aduce frecuentísimamente su testimonio al paso de muchísimos asuntos de diversa índole, que ilumina con versos del poeta de Sulmona - Feijoo mismo se refirió a las «buenas explicaderas» de Ovidio en TCU, I, III, § IX, 47; 1726 - : ya sea para arrojar su testimonio contra Raimundo Lulio [Ramón Llull] (CEC, II, XIII, 2; 1745), aludir a la Edad del Hierro (TCU, I, III, § IX, 33; 1726), recordar el origen del brindis (CEC, II, XIV, 17; 1745), definir a una Quimera (CEC, III, XXX, 9; 1750) o a una Sirena (TCU, VI, VII, § VIII, 41; 1734), valerse de su testimonio geográfico (TCU, V, XV, § X, 25; 1733 y CEC, II, XV, 20; 1745) $\mathrm{u}$ ofrecer diversos consejos sobre el amor y las costumbres amatorias (TCU, II, VI, § V, 21; 1727; TCU, VII, X „§ XIX, 97; 1736; TCU, VII, XVI, § III, 13; 1736; TCU, VII, § IV, 10; 1736), todo lo cual no impide que acabe por apellidarlo «lascivo» (CEC, V, XXIII, 11; 1760), aunque no es menos cierto que lo considera un poeta a la altura de los más grandes, Virgilio y Horacio (TCU, I, XIV, § XII, 51; 1726), y que encareció a menudo su estilo y capacidad poéticos ${ }^{36}$. Como en el caso de Virgilio, también se preocupó Feijoo de registrar aquellas veces en que Ovidio parece referirse a diferentes hechos de la Historia Sagrada ${ }^{37}$.

Debemos recordar por último, no obstante, la importancia que Ovidio tiene en el concepto feijoniano de poesía y los múltiples testimonios que en su definición de la poesía Feijoo toma de Ovidio. En primer lugar, Feijoo se vale de él para definir qué entiende por poesía, y así nos dice que «quien quiere que los poetas sean muy cuerdos quiere que no haya poetas. El furor es la alma de la poesía. El rapto de la mente es el vuelo de la pluma: Impetus ille sacer, qui vatum pectora nutrit, dijo Ovidio [Pónticas, IV, 4, v. 25: "El ímpetu sagrado del que se nutre el pecho de los poetas"]» (TCU, I, XV, § VI, 32; 1726), donde claramente

36 Recuerda una bella imagen de Ovidio: «Así esta voz latina viene a ser como versión de la griega pyropus, usada ya también entre los latinos, derivada de Pyr, que en lengua griega es fuego. Por esta imitación del fuego, que resplandece en el rubí, dijo Ovidio, colocándole por adorno en la casa del sol: Flammasque imitante pyropo.» [Metamorfosis, II, v. 2: “[El Palacio del Sol] resplandecía imitando el pyropo [aleación compuesta por cuatro partes de cobre y una de oro]"] (TCU, II, II, § VI, 40; 1728).

37 Con respecto a la relación de Ovidio con la Historia Sagrada, primero anota que Evoa en sus poemas no es la primera mujer, sino una interjección, equivalente a Bene sit Illia TCU, V, VIII, § VII, 41; 1733. Después, considera plausible que «en el libro primero de los Metamorfoseos de Ovidio está desfigurado algo de lo que Moisés escribió en los primeros capítulos del Génesis; como la Creación, la delincuente osadía de los que la Escritura llama gigantes, la universal corrupción de los hombres y el Diluvio. Pero no es lo mismo pretender que una u otra fábula se derive de la Historia Sagrada que hacer de esta derivación sistema general para todos los errores del paganismo. Y aun respecto de esas pocas fábulas se debe proponer la derivación como probable, no como cierta; por la razón que ya hemos insinuado de que pudo ser casual la semejanza del error a la verdad» (TCU, V, VIII, § VII, 43; 1733). 
puede percibirse que era para Feijoo el «entusiasmo» uno de los constitutivos esenciales de la poesía. En segundo lugar, Ovidio es aducido a la hora de explicar el no sé qué, lo que resulta de gran relevancia para probar la filiación clásica del no sé qué feijoniano ${ }^{38}$. Por último, el de Sulmona se revela trascendental a la hora de advertir la importancia que Feijoo concedía a la imitación de la naturaleza en el poema. El benedictino reprocha a Ovidio el exceso de dulzura poética de que hace gala en aquellos momentos en que por referirse a hechos trágicos debía ser más áspera su lira para mejor imitar la realidad: «¡Con cuánta más razón se podía exclamar aquí con la censura de Séneca contra Ovidio, porque en la descripción de un objeto tan trágico como el Diluvio de Deucalión [Metamorfosis, I, vv. 313 y siguientes] introdujo algún verso tanto cuanto ameno!» (TCU, I, XIV, § IX, 33; 1726; sobre lo mismo volverá en TCU, IV, XIV, § XV, 41; 1730).

\section{Horacio, «el mejor lírico de los latinos»}

Horacio, indudablemente, también merece mención aparte. Es un poeta de gran relevancia para Feijoo, no solo por su calidad poética, que a ojos del de Casdemiro le hace ser, según cita en CEC, V, XXIII, 10; 1760, el «mejor poeta lírico de los latinos» — no debemos perder de vista que Virgilio y Lucano no eran poetas líricos—, sino también por su trascendencia moral. Así, Horacio es utilizado para defender ideales de pobreza (TCU, I, III, § III, 12; 1726) y virtud (TCU, I, VII, § I, 1; 1726) o para criticar el amor propio (TCU, VI, XIII, § I, 1; 1734) y abundar en el tan horaciano como feijoniano menosprecio de corte (CEC, III, XXV, 1; 1750). Incluso cristianiza a Horacio y lee en él cierto escepticismo para con los dioses paganos ${ }^{39}$. Es más, estos mismos versos que sirven de pretexto para ver en Horacio a un poeta crítico con las deidades romanas se

38 «Ovidio, habiendo observado que algunos escitas, conducidos a Roma, no perdían ocasión alguna de volverse fugitivos al áspero clima donde habían nacido, atribuye esto a una dulzura oculta (que él mismo, con tener tan buenas explicaderas, no acierta a explicar) o como facultad simpática y virtud magnética con que atrae a cada uno su propia patria; y así lo deja en un no sé qué: Nescio qua natale solum dulcedine cunctos /Trahit, \& inmemores non sinit esse sui. / Quid melius Roma? Scythico quid frigore pejus? / Huc tamen ex illa barbarus urbe fugit» [Pónticas, I, 3, vv. 35-38: No sé cómo la dulzura del suelo natal / nos atrae y no permite que lo olvidemos. / ¿Qué hay mejor que Roma? ¿Qué peor que el frío escítico? / Y, sin embargo, el bárbaro huye desde esa ciudad hasta aquí] (TCU, I, III, § IX, 47; 1726; lo repite en TCU, III, X, § II, 6; 1730).

39 «En orden a los antiguos idólatras ya algunos eruditos esforzaron bien esta duda, proponiendo sólidos fundamentos para pensar que en el simulacro no se adoraba el tronco, el metal o el mármol, sino algún numen que se creía huésped en ellos. Verdaderamente parece increíble que un estuario, como le pinta graciosamente Horacio en una de sus sátiras, enarbolada la hacha con una mano, asido un tronco con la otra, perplejo sobre si haría un Príapo o un escaño, considérase en sí mismo la autoridad que era menester para fabricar una deidad [Sátiras, I, 8, vv. 1-3]» (TCU, II, XV, § VII, 27; 1745). 
reinterpretan más adelante para encontrar en ellos otro modelo virtuoso: el del poeta humilde consciente de las limitaciones de su obra ${ }^{40}$.

Es asombroso advertir cuánto la práctica poética de Horacio y su trascendental Epístola a los Pisones han influido sobre Feijoo, toda vez que de ambas toma muchas de sus propias ideas preceptivas, incluso en aquellos lugares en los que la crítica, paradójicamente, ha creído ver más arrebato libertario feijoniano.

Cuando Feijoo proclama la importancia del ingenio del poeta, esto es, de su talento natural, en realidad no está haciendo más que parafrasear los siguientes versos de Horacio:

\section{Natura fieret laudabile carmen an arte, quaesitum est. Ego nec studium sine divite vena nec rude quid prosit video ingenium; alterius sic altera poscit opem res et coniurat amice.}

(Horacio, Epístola a los Pisones, vv. 408-411)
Mucho se ha debatido si el poema
es por naturaleza o es por arte
merecedor de elogio. Yo no veo
de qué puede servir solo el estudio
sin una rica inspiración. Tampoco
solo el talento en bruto. Cada uno
de los dos solicita ayuda al otro
y se conjuran como dos amigos ${ }^{41}$.

Horacio es además singularmente importante porque a él acude Feijoo como autoridad a la hora de considerar accesoria la ficción en el poema. Y,

40 «Pinta el poeta un estatuario o carpintero con un tronco de higuera en las manos, dudoso al principio si haría de él un escaño o un dios, que llamaban Príapo, y resuelto después a hacer esto segundo: Olim truncus eram ficulnus, inutile lignum: / cum faber incertus Scamnum faceret, ne Priapum, / maluit esse Deum. [Sátiras, I, 8, vv. 1-3: Yo era un tronco de higuera, inútil leño, / cuando un artesano que no sabía si hacer un escaño o un Príapo / decidió que yo fuese un dios] [...] [Está] claro que Horacio en ellos [estos versos] habla irrisoriamente de la estúpida superstición del artífice, como de otras que refiere en la misma sátira, y así la concluye diciendo al lector que no podría ver aquellas cosas sin gran desprecio y risa: Cum magno risuque, jocoque videres [Sátiras, I, VIII, v. 50: si lo hubieras visto visto, te hubiera provocado mucha risa y jocosidad]. Luego aunque en el artífice y otros vulgares reinase aquella crasa superstición, estaba muy libre de ella Horacio, y por consiguiente todos, o los más, hombres de entendimiento que había en Roma; pues si todos los demás estuviesen en aquella crasa persuasión, es claro que no se atrevería Horacio a hacer públicamente irrisión de ella» (IA, § I, 10; 1729).

41 Horacio, Arte Poética, introducción, traducción, notas y comentario de Juan Antonio González Iglesias, Madrid, Cátedra, 2012, pág.123. 
al hacerlo, no podía Feijoo más que recordar el célebre Ut pictura poesis. Así, explica Feijoo que

[...] la poesía [es] un arte perfectamente análogo al de la pintura, como saben todos los que saben algo, y apenas hay quien ignore lo de Horacio: Ut Pictura Poesis erit [Epístola a los Pisones, v. 361: Como la pintura, así la poesía]: igualmente podrán ser objetos propios del poeta, como lo son del pintor, los hechos o personajes verdaderos y reales y no solo los fabulosos. Realmente también el poeta representa, como el pintor; y el pintor describe como el poeta. En la mano de aquel es pincel la pluma; y es pluma el pincel en la mano de éste. La poesía es una pintura parlante y la pintura una poesía muda (CEC, V, 19, 14; 1760).

Este mismo surco horaciano sigue Feijoo cuando, además, recuerda que la poesía debe instruir a los lectores; de hecho, considera Feijoo que de ahí procede el prestigio del poeta, y para ello vuelve a convocar a Horacio, quien cantó que los antiguos poetas se ocuparon de enseñar con sus versos y hacer avanzar la educación de los hombres:

Orfeo y Anfión, por testimonio de Horacio, cantaron instrucciones religiosas, morales y políticas, con que redujeron los hombres de la feroz barbarie en que vivían a una sociedad racional y honesta. De aquí vino la fábula de amansar con la lira tigres y leones y atraer las piedras. Y es muy de notar que después de exponernos esto Horacio añade que este fue el fundamento del honor que se dio a los poetas y a sus versos: Sic honor et nomen Divinis Vatibus, atque / Carminibus venit [Epístola a los Pisones, vv. 400-401: Así honor y fama divinos alcanzaron a los antiguos poetas y a sus cantos] (TCU, IV, XIV, § XV, 39, Adición 9).

Además, Horacio se utiliza, como ya vimos, para subrayar la capacidad propedéutica de la poesía (TCU, IV, XIV, § XV, 39, adición 9; 1740), entre otras virtudes que Feijoo consideraba propias del verso, como la versificación o musicalidad (CEC, V, XXI, 17; 1760) o los peligros inherentes a la imitación ciega de modelos literarios, que preocupó mucho a Feijoo, y a la que atacó

[...] siguiendo a Horacio, de quien es aquella invectiva: ;Oh imitatoris servum pecus! [Epístolas, I, 19, v. 19: ¡Oh, imitadores, rebaño de siervos!]. [Puede afirmarse que la copia irreflexiva es peligrosa porque] en esto, como en otras muchas cosas, cada hombre tiene su carácter que le distingue y hace distinguir por los que son dotados de algún conocimiento, los cuales disciernen muy bien lo que es copia y cuánto dista ésta de la perfección del original (CEC, II, VI, 8; 1745). 
Marcial es citado elogiosamente y llega a ser definido como uno de los grandes poetas hispanos (TCU, IV, XIV, § XV, 39; 1730), pues nadie puede cuestionarle «el principado de las agudezas y sales jocosas» (TCU, IV, XII, § XVI, 40; 1730). No hay que perder de vista, tampoco, que Feijoo lo utiliza para atacar a los médicos (JR, § VII, Reflexión III; 1749). Ahora bien, Marcial es un poeta que incomoda en ocasiones al benedictino, y de él proclama que le «ofende la continuada y aun escandalosa chocarrería» (CEC, V, XVII, 9; 1760); y eso que Feijoo leía a Marcial en una antología purgada de los epigramas más irreverentes: «Del ejemplar de Marcial que yo tengo justísimamente excluyó el editor los muchos epigramas obscenos que se hallan en otras ediciones» (CEC, V, XIX, 5 1760). Como consecuencia, nos dice Feijoo que Marcial le parece en ocasiones demasiado chabacano, como cuando entiende que «Vulgarísimo es el Marcial [en poemas como]: Crine ruber, niger ore, brevis pede, lumine luscus, / Rem magnam praestas, Zoile, si bonus es» [Epigramas, XII, 54: Con el cabello pelirrojo, la tez morena, la pata coja, el ojo bizco, / mucho haces, Zoilo, con ser bueno] (TCU, V, II, § X, 31, Adición, 2; 1740).

Al paso del Pleito de Lucano, Feijoo utilizó a Marcial como auctoritas que se muestra del lado del de Córdoba frente a Virgilio. Sucedió que, en 1760, y en el último texto que Feijoo diera a las prensas, el quinto tomo de las Cartas eruditas, hubo de confesar Feijoo de dónde había tomado las valoraciones positivas que Marcial y Estacio ${ }^{42}$ dan de Lucano, pues había sido acusado de falsear las fuentes en su favor. Como nos explica, ha tomado sus citas de segunda mano, pues las ha extraído de la obra de Thomas Pope-Blount Censura celebriorum Authorum [Feijoo usa la edición de Génova de 1710], en cuya página 112, explica, puede leerse «A Stacio et Martiale, non solum collatus [Lucanus] Maroni, verum etiam praelatus» [Estacio y Marcial no solo le concedieron [a Lucano] igualdad con [Publio Virgilio] Marón, sino preferencia] (CEC, V, XIX, 4; 1760). Empero, relata Feijoo haber inquirido en su edición de Marcial tal valoración sin encontrarla, si bien ya sabemos que manejaba una edición antológica. Reconoce Feijoo que con esta información no puede probar que Marcial estimase a Lucano por encima de

42 Feijoo se vale de él como auctoritas, y no olvida así contar con el nombre de «Estacio, el cual dos veces le da la preferencia [a Lucano sobre Virgilio] de los versos que compuso, solemnizando después de muerto Lucano el día de su nacimiento. La primera, cuando dijo: Baetim Mantua Provocare noli [Silvas, II, 7, v. 35: No quieras, Mantua, desafiar al Betis (en clara referencia a Virgilio)]; la segunda, cuando después de concederle ventajas sobre Ennio, Lucrecio, Valerio Flaco y Ovidio, añadió: Quin Majus loquor, ipsa te Latinis Aeneis venerabitur conantem [Silvas, II, 7, v. 80: Diré algo aún mayor: la Eneida te venerará cuando cantes al pueblo latino]. Contémplese de cuánto peso es Estacio en materia de Poesía, a quien Lipsio llamó grande y supremo poeta: Sublimis et celsus, magnus et summus poeta [Admiranda, III, 7, 6: Sublime y excelso, magno y alto poeta]» (TCU, IV, XIV, § XV, 39, Adicción, 1; 1740). 
Virgilio, pero sí haber obrado de buena fe, que es, según él, lo principal en su defensa. Reitera luego su favor por Lucano y enumera la pequeña liga de hombres ilustres que participan de su opinión y que ya conocemos (CEC, V, XXI, 7; 1760).

Aunque Feijoo no encontrase en su ejemplar la defensa que Marcial hace de Lucano, sí lo hemos hecho nosotros, lo que tiene además particular relevancia porque Mayans, en una de sus apostillas a Feijoo, le había hecho notar nada menos que «dice V. Rma. que Marcial dio a Lucano la preferencia sobre Virgilio. Yo no me acuerdo haber leído esto en Marcial. Pero sí lo contrario, Lib. 7, Epig. 22, que empieza Phaebe veni ${ }^{43}{ }$. El hecho es que Marcial dedica repetidos elogios a Lucano y a su viuda, Pola (esencialmente en VII, 21, 22, 23, pero no exclusivamente), pues Lucano primero, y Pola después, fueron valedores suyos y lo auxiliaron en cuanto pudieron. El epigrama que Mayans cita erróneamente (pues menciona el epigrama VII, 22, cuando el que principia «Phaebe veni» es el VII, 23), constituye, de hecho, un típico texto de encomio o laudatio del amigo muerto dirigido por Marcial a Lucano ${ }^{44}$.

Juvenal, quien «discretamente satirizaba»

El interés que Feijoo manifiesta por Juvenal es solidario del que también sentirá por Quevedo, pues son parecidas las vetas poéticas de uno y otro que a Feijoo más le interesan. Es llamativo que Feijoo cite y utilice versos de Juvenal que ya fueron citados y utilizados por Quevedo: Juvenal es una fuente habitual cuando Feijoo entona el menosprecio de corte y alabanza de aldea; a tal efecto, también empleó Quevedo a Juvenal en su soneto «Si gobernar provincias y legiones...», basado de hecho en la «Sátira I». El caso, en fin, es que Juvenal es citado por Feijoo como gran poeta (TCU, IV, XII, § XVI, 40; 1730 y CEC, V, V, $22 ; 1760) ; y$, es más, incluso reconoce el benedictino la influencia — pero no el plagio— de la «Sátira $X$ » en su «Discurso sobre la humilde y alta fortuna» de TCU, I, III; 1726 (JR, § VIII, Reflexión IV; 1749). Generalmente, Juvenal es empleado por Feijoo cada vez que quiere denunciar un mal hábito o reconvenir a un pecador. Así, el Juvenal satírico es aducido para criticar a los médicos ${ }^{45}$,

\footnotetext{
43 «G. Mayans a Benito Feijoo, 18 febrero de 1733», en Antonio Mestre, «Correspondencia FeijooMayans en el Colegio del Patriarca», Anales del Seminario de Valencia, IV, 8 (1964), págs. 149-185; la cita en pág. 176.

44 Marcial, Epigramas (2 vols.), traducción y notas de Antonio Ramírez de Verger, Gredos, Madrid, 2002, vol. II, págs. 17-18.

45 «Themison, discípulo de Asclepíades, luego que éste expiró, alteró toda la doctrina de su maestro y se hizo caudillo de la secta de los Metódicos, que no debió de granjearse gran aplauso en Roma, cuando Juvenal, hablando de los Sectarios debajo del nombre de su jefe, cantó: Quot Themison aegros autumno occiderit
} 
reprobar a una mujer muy locuaz ${ }^{46}$, mofarse de quienes creen que todo lo antiguo es mejor ${ }^{47}$, criticar a los que sabiendo que están en un error no quieren admitirlo por orgullo ${ }^{48}$, hacer menosprecio de corte ${ }^{49}$, como acabamos de apuntar, o poner en duda la fiabilidad de los méritos académicos ${ }^{50}$.

En esto, Feijoo se adelanta de nuevo a la generación ilustrada, que hará de Juvenal el satírico moralista por excelencia. Los dos grandes autores satíricos del momento serán Horacio y Juvenal, pero ambos representarán dos enfoques muy distintos de la sátira: Horacio es más bienhumorado y dulce, y parece hacer suyo el ideal del castigat ridendo mores propio de la comedia; Juvenal, por su parte, es más violento y hostil con cuanto critica; no en vano, él mismo afirma que indignatio fecit versos [Sátiras, I, v. 79: «Dicta la indignación los versos»]. A tal efecto, conviene recordar que Jovellanos, por ejemplo, colocará una cita de Juvenal al inicio de sus propias sátiras ${ }^{51}$.

uno [«Los enfermos que Temisón ha liquidado en un solo otoño», Sátiras, X, v. 221]» (TCU, I, V, § III, 18; 1726, repetido luego en CEC, II, VIII, 10; 1745).

46 «En aquellos tiempos rudos, cuando se ignoraba la causa natural de los eclipses, no es de extrañar, que sobre ellos concibiesen los hombres extravagantes ideas. Así (según refiere Plinio) Estesícoro y Píndaro, ilustrísimos poetas, consintieron en el error vulgar de su siglo, atribuyendo a hechicería o encanto la obscuridad de los dos luminares. Por esto era rito constante entonces dar todos grandes voces y hacer estrépito con tímpanos, vacías y otros instrumentos sonoros a fin de turbar o impedir que llegasen al cielo las voces de los encantadores. A lo que aludió Juvenal cuando de una mujer muy locuaz y voceadora dijo: Una laboranti poterit sucurrere Lunae» [«Ella sola en acción podrá socorrer a la luna» (Sátiras, VI, v. 443)] (TCU I, IX, § I, $2 ; 1726)$.

47 «Discretamente satirizaba Juvenal a los antiguos que pesaban las excelencias del mérito por cuatro años más de ancianidad: Venerabile erat praecedere quatuor annis» [Sátiras, XIII, v. 58: "Muy venerable era preceder en cuatro años"] (TCU, II, Dedicatoria del Autor; 1728).

48 «Y lo que es peor, no faltan algunos que, llegando a desengañarse de la falsedad de sus ancianas opiniones en este o en aquel punto filosófico, no quieren confesarlo, o porque tiene por oprobio la retractación o porque juzgan desdoro suyo que los que son más nuevos que ellos logren el triunfo de dar a conocer que hallaron la verdad que ellos inútilmente y por senda errada buscaron tanto tiempo. Aquí lo de Juvenal: Vel quia turpe putant parere minoribus et quae / Imberbes didicere, senes spernenda fateri. [Feijoo se equivoca en la cita, pues este fragmento es de Horacio, y puede leerse en Epístolas, II, I, vv. 84-85: les parece que es vergonzoso hacer caso a los jóvenes / y admitir de viejos que deben olvidar lo aprendido de imberbes]» (TCU, II, I, $\S X, 55 ; 1728)$.

49 Juvenal «claramente insinúa que en Roma el que no fuese mentiroso y adulador no tenía que esperar ni aun que hacer: Quid Romae faciam? Mentiri nescio: librum / Si malus est, nequeo laudare.» [Sátiras, III, vv. 41-42: ¿Qué haré en Roma? Mentir no sé; / un libro, si es malo, no soy capaz de alabarlo] (TCU, VII, $10, \S \mathrm{IV}, 16 ; 1736)$.

50 «Los honores adquiridos imponen muchas veces para la existimación de sabiduría, porque son pocos los que tienen presente lo de Juvenal: Ergo, ut miremur te, non tua; primum aliquid da, / Quod possim titulis incidere praeter honores» [Sátiras, VIII, vv. 68-69: Así que para que te admiremos a ti, da algo personal tuyo / que pueda mandar grabar en las inscripciones] (CEC, III, IV, 2; 1729).

51 Elena de Lorenzo, «El sangriento furor de Marte. Poesía épica del siglo XVIII», en Jesús Lara Garrido y Raúl Díaz Rosales (eds.), El canto de Calíope. Antología crítica de estudios de épica culta, Anejos de Analecta malacitana, LXXV (2013), en prensa. Así, Jovellanos encabeza su «Sátira primera a Arnesto» con la cita de Juvenal «Quis tam patiens ut teneat se?» [Sátiras, I, v. 30: ¿Quién será tan paciente como para contenerse?]. 
Los poetas españoles que Feijoo cita en su obra ensayística de manera elogiosa y recurrente son los siguientes: Juan de Mena, Garcilaso de la Vega, Diego Hurtado de Mendoza, fray Luis de León, Santa Teresa de Jesús, Félix Lope de Vega, Bartolomé Leonardo de Argensola, Juan de Jáuregui (como traductor, en especial de La Farsalia), Luis de Góngora, Francisco de Quevedo, Sor Juana Inés de la Cruz, Antonio de Solís, Agustín Moreto, Pedro Calderón de la Barca y Francisco Bernaldo de Quirós. Mención aparte merece Cervantes ${ }^{52}$.

La lista ofrecida por Feijoo es no obstante susceptible de ser mucho más afinada, porque, por sorprendente que resulte, varios de estos poetas no son citados por su obra en verso, sino únicamente por cuanto escribieron en prosa: es el caso de fray Luis de León ${ }^{53}$, Bartolomé Leonardo de Argensola ${ }^{54}$, Santa Teresa de Jesús ${ }^{55}$

52 Feijoo nunca cita a Cervantes, ni como prosista ni como poeta, peculiaridad que ya notó Gregorio Marañón (Las ideas..., pág. 108, n. 3), aunque parece fuera de toda duda que lo había leído, como evidencian su prosa, de sabor cervantino, o su rechazo de la ficción exagerada; el cervantismo de Feijoo, particularmente en lo tocante a su sentido del humor, ha sido advertido por Inmaculada UrZainQui («La ilustración sonriente: Feijoo y la risa», Bulletin Hispanique. Hommage à François Lopez, 1 (2002), págs. 443-489). Por su parte, Jon Juaristi, en su conferencia «El Padre Feijoo», dictada en la Fundación Juan March el 13 de abril de 2007 y disponible en línea en http://www.march.es/conferencias/anteriores/voz. aspx?id=1545\&l=2, apuntó que «la influencia de Cervantes en Feijoo es constante», lo que ejemplifica recordando que la renuncia feijoniana a escribir en latín tiene no poco que ver con la justificación de Cervantes en el prólogo del Quijote. Además, en uno de sus poemas burlescos, Feijoo utiliza a Don Quijote cuando dice, atacando a un poeta rival, «Todo caballero andante / sabré meter en un cesto / porque soy en un supuesto / Don Quijote y Rocinante». Justo E. Areal, Poesías inéditas del Padre Feijoo, Tuy, Tipografía Regional, 1901, pág. 43.

53 Fray Luis es aludido por Feijoo únicamente en el marco de la polémica lulista. Al parecer, los partidarios de Raimundo Lulio [Ramón Llull] utilizaban a su favor una supuesta cita del «doctísimo M. Fr. Luis de León, concebida en estas voces: Tres sabios tuvo el mundo, Adán, Salomón, y Raimundo.», cita que Feijoo se niega a dar por buena, explicando que es indicio suficiente de que esa no era la opinión de fray Luis el hecho de que no se indique el lugar de sus obras del que se toma el adagio (CEC, II, XIII, 46; 1745). Añade Feijoo, luego, reafirmándose en su opinión: «¿̨ni cómo es posible que un hombre tan sabio como el Maestro Fr. Luis de León dijese un disparate tan garrafal? La proposición Tres sabios tuvo el mundo, Adán, Salomón, y Raimundo es, según su sentido natural y literal, exclusiva de todos los demás; por consiguiente se les niega el atributo de sabios a cuantos Doctores y Padres tuvo hasta ahora la Iglesia» (CEC, II, XIII, 47; 1745). Sobre idéntico tema volverá, de nuevo en el marco de la discusión lulista, en CEC, III, XXVI, 23; 1750.

54 Feijoo se refiere a la Historia de la conquista de las Malucas, de Bartolomé Leonardo de Argensola en TCU, IV, VI, § VII, 25; 1730. Más tarde, criticando a Gonzalo de Illescas, Feijoo utiliza a Argensola como fuente de autoridad: «¿mas cómo Illescas pudo padecer un error tan craso en orden a un suceso de su tiempo? Para satisfacer a esta pregunta, no he menester valerme de la crítica que de este escritor hizo Leonardo de Argensola, de quien no dudó decir que había sido fácil en creer, y ligero en escribir"» (TCU, VI, III, § VIII, $17 ; 1734)$.

55 Feijoo se pregunta, refiriéndose a ella, «¿qué autor latino escribió con más claridad y copia la mística que Santa Teresa?» (TCU, I, XV, §5, 22; 1726). Y, más adelante, afirma: «los mismos franceses admiran y ponderan como cosa altísima y de lo más sublime que hasta ahora se ha escrito en este género, las obras de Santa Teresa» (TCU, IV, XIV, § XXI, 68; 1730). Como prueba de la estima que Feijoo sintió por Santa Teresa, 
debe recordarse el «Villancico a Santa Teresa», poema inédito de Feijoo del que da noticia, añadiendo un breve comentario sobre él, Dionisio Gamallo Fierros («La poesía de Feijoo», Boletín de la Biblioteca Menéndez Pelayo, XL (1964), págs. 117-165; poema y glosa en págs. 153-155.)

${ }_{56}$ Feijoo acude repetidas veces a su Historia de Méjico, traducida incluso al francés a causa de su mucho mérito (TCU, IV, XIV, § XVI, 50; 1730). Se destaca que criticase la política del Cardenal Cisneros (TCU, I, IV, § XIII, 49; 1726 y CE II, I, 7; 1745), también su «elegancia y pureza» (TCU, I, XV, §5, 20; 1726) y su primor estilístico (TCU, IV, VIII, § VI, 16; 1730), imitado incluso, aunque sin alcanzar el modelo, por el Conde de Erizeira (CEC, II, VI, 8; 1745), así como que llamase «de Otumba» al «Valle de Otumpa», en el que españoles y mejicanos libraron una famosa batalla (TCU, I, XVI, § 7, 44; 1726).

57 Antonio de Solís fue un poeta muy apreciado por Feijoo, y de él dijo que «fue sin duda nobilísimo ingenio que entendió bien todos los primores de la poesía, excediéndose a sí mismo y excediendo a todos en pintar los afectos con tan propias, íntimas y sutiles expresiones, que parece que los da mejor a conocer su pluma que la experiencia» (TCU, I, XIV, § 12, 48; 1726), si bien se manifestó a disgusto con algunas de sus coplas a lo divino: «Solís, como otros poetas de habilidad, a estas letrillas que se hacen para las festividades las han mirado como cosa de juguete, siendo así que ninguna otra composición pide atenderse con tanta seriedad. ¿Qué asunto más noble que el de estas composiciones, donde ya se elogian las virtudes de los Santos, ya se representa la excelencia de los Misterios y atributos divinos? Aquí es donde se habían de esforzar más los que tienen numen» (TCU, I, XIV, § 12, 49; 1726). En CEC, II, VII, 82-83; 1745, Feijoo recuerda los versos finales de un soneto bien resuelto de Solís.

58 Destaca Feijoo a Lope como creador de la «poesía cómica» española: «no sería justo omitir aquí que la poesía cómica moderna casi enteramente se debe a España; pues aunque antes se vio levantar el teatro de Italia, lo que se representaba en él más era un agregado de conceptos amorosos que verdadera comedia, hasta que el famoso Lope de Vega le dio designio, planta y forma. Y si bien que nuestros cómicos no se han ceñido a las leyes de la comedia antigua, lo que afectan mucho los franceses, censurando por este capítulo la comedia española, no nos niegan estos la ventaja que les hacemos en la inventiva, por lo cual sus mejores autores han copiado muchas piezas de los maestros. Óigase esta confesión a uno de los hombres más discretos en verso y prosa que en los años próximos tuvo la Francia, el señor de San Evremont: Confesamos (dice) que los ingenios de Madrid son más fértiles en invenciones que los nuestros; y esto ha sido causa de que de ellos hayamos tomado la mayor parte de los asuntos para nuestras comedias, disponiéndolos con más regularidad y verisimilitud. Esto último no deja de ser verdadero en parte, pero no con la generalidad que se dice. $L a$ princesa de Elide de Moliere es indisimulable y claro traslado de El desdén con el desdén de Moreto, sin que haya más regularidad en la comedia francesa. La verisimilitud es una misma, porque hay perfecta uniformidad en la serie sustancial del suceso; sólo se distinguen las dos comedias en las expresiones de los afectos, y en esto excede infinito la española a la francesa.» (TCU, IV, XIV, §15, 45; 1730). Además, haciendo gala de su erudición histórico literaria, hace notar Feijoo que fue a «doña Bernarda Ferreyra», a quien «nuestro famoso Lope de Vega hizo tanto aprecio del extraordinario mérito de esta señora, que le dedicó su Elegía intitulada la Fylis» (TCU, I, XVI, § XVI, 113; 1726), para acabar citando la María Estuarda de Lope de Vega como ejemplo de poesía sin ficción al calor del Pleito de Lucano (CEC, III, V, 7; 1750).

59 Hablando de hasta qué punto puede el nombre de alguien determinar su personalidad (idea de la que Feijoo descree completamente), Feijoo apunta que «sólo puede admitirse esta ficción, más que poética, para entremés de la comedia de Calderón Dicha y desdicha del nombre» (TCU, II, III, § IV, 34; 1728). También hace referencia el benedictino a la obra dramática en que Calderón teatralizó la historia del soldado Oeno, quien penetró en el purgatorio de San Patricio. Así, Feijoo explica que este suceso «aunque anda vulgarizado en una comedia de nuestro discretísimo y agudísimo cómico D. Pedro Calderón de la Barca, intitulada $E l$ Purgatorio de S. Patricio, este autor usó de la licencia poética, alterándole en una u otra circunstancia, como también desfiguró algo el nombre del soldado» (TCU, VII, VI, § IV, 8; 1736).

60 Véase la nota 58. 


\section{Poetas españoles citados por Feijoo}

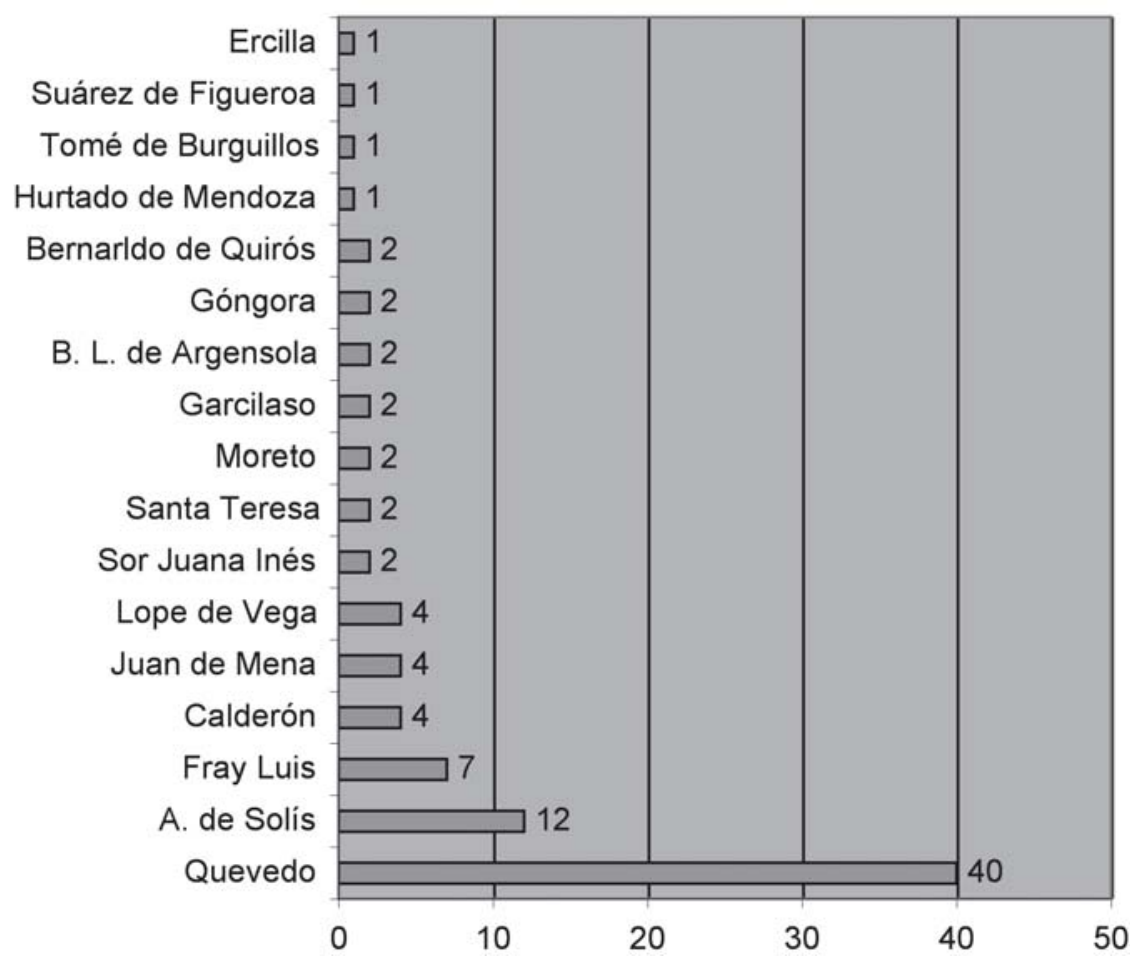

mente Juan de Mena ${ }^{61}$, Garcilaso de la Vega ${ }^{62}$, Sor Juana Inés de la Cruz ${ }^{63}$, Góngora, Quevedo y Bernaldo de Quirós, si bien serán estos últimos cuatro nombres

${ }^{61}$ Juan de Mena es utilizado en realidad por Feijoo como una fuente histórica cuando pretende historiar la vida de Enrique de Villena. Así, se aduce una carta del Bachiller Fernán Gómez de Ciudad Real, enviada al «famoso poeta D. Juan de Mena», en la que aquel se refiere a la quema de los libros de Enrique de Villena (TCU, VI, II, § IX, 89; 1734); más adelante, Mena reaparece, de nuevo en relación con Villena: en este caso, se reproducen algunos versos que le dedicara: «aquel que tú ves estar contemplando / en el movimiento de tantas estrellas...» [El laberinto de Fortuna, Octava CXXVI, vv. 1-2 y siguientes] (TCU, VI, II, § IX, 93; 1728).

${ }^{62}$ Pese a la importancia histórica del testimonio (Garcilaso no sería reeditado hasta treinta y nueve años más tarde, en 1765), Feijoo no dedica ningún comentario en profundidad a la poesía de Garcilaso, y solamente cita su nombre como ejemplo preclaro de gran poeta (TCU, I, XV, §5, 22; 1726).

63 Refiriéndose a sus cualidades, dice Feijoo que «la célebre monja de México Sor Juana Inés de la Cruz es conocida de todos por sus eruditas y agudas poesías; y así es excusado hacer su elogio. Sólo diré que lo menos que tuvo fue el talento para la poesía, aunque es el que más se celebra. Son muchos los poetas españoles que le hacen grandes ventajas en el numen; pero ninguno acaso la igualó en la universalidad de noticias de todas facultades. Tuvo naturalidad, pero faltóle energía». Ahora bien, con respecto a su prosa, dice que «la Crisis del Sermón del P. Vieyra acredita su agudeza; pero haciendo justicia es mucho menor que la de aquel incomparable jesuita a quien impugna. ¿Y qué mucho que fuese una mujer inferior a aquel hombre, a quien en pensar con elevación, discurrir con agudeza y explicarse con claridad no igualó hasta ahora predicador alguno?» (TCU, I, XVI, § XVI, 115; 1726); también, que «si discurrimos por las mujeres sabias y agudas, sin ofensa de alguna se puede asegurar que ninguna dio tan altas muestras (que saliesen a la luz pública) como la famosa monja de México Sor Juana Inés de la Cruz» (TCU, IV, VI, § VII, 27; 1730). 
a los que Feijoo concederá más atención, particularmente a Quevedo, quizá su escritor español favorito ${ }^{64}$.

Góngora, «muchas las composiciones suyas que hechizan» $y$ «muchas las insufribles»

En cualquier caso, la nómina que Feijoo nos ofrece es muy interesante y de gran relevancia, porque, si nos fijamos, siguen predominando todavía los autores barrocos, aunque más bien aquellos que encarnan una línea clásica aun dentro del Barroco. Góngora es probablemente el poeta de la lista que más difícilmente parece conciliarse con la crítica de la poesía tardobarroca que Feijoo lidera, pero sucede que Feijoo se aproxima claramente en su lectura de Góngora a la que después harán de él los neoclásicos; esto es, prefiriendo al Góngora de arte menor, el de los romances y las letrillas, el Góngora «Príncipe de la luz», por decirlo de una vez, orillando al poeta oscuro de las Soledades y el Polifemo.

Así, aunque no podamos deducir de sus alusiones a Góngora en el Teatro crítico universal y las Cartas eruditas y curiosas esta preferencia ${ }^{65}$, es una carta de Feijoo, dirigida al P. Sarmiento y fechada el 6 de enero de 1742, reproducida por Marañón ${ }^{66}$, la que nos da prueba de esta lectura

Pienso que la perfecta naturalidad de nuestra poesía se acabó en el mismo [instante] en que subió al más alto punto la intumescencia del verso. Hablo de Góngora. Este poeta compuso en uno y otro extremo. Son muchas las composiciones suyas que hechizan por su dulcísima naturalidad, y muchas las insufribles por la afectación vana de cultura. Pero el mal es que siendo la naturalidad prenda inexcusable en la poesía y sin la cual las demás nada valen, son muy pocos los

64 Dice Marañón que Quevedo interesó mucho a Feijoo, aunque debemos destacar, como luego demostraremos, que si bien Feijoo se detuvo en el Quevedo poeta, le atrajo mucho el Quevedo moralista y, también, el Quevedo antimédico. Gregorio Marañón, Las ideas biológicas del Padre Feijoo, Madrid, Espasa, 1941 [1. ${ }^{a}$ ed. 1934], pág. 108, n. 3.

65 Góngora aparece citado como ejemplo paradigmático de utilización de la lengua castellana en poesía en TCU, I, XV, §5, 22; 1726, y también como autoridad junto a otros grandes autores en el examen al que diferentes sabios sometieron al «niño de nueve a diez años que hoy vive en París y es asombro de París y de toda Francia»: «explicó [el niño prodigio nacido en Madrid en 1721] los lugares más difíciles de Homero, Anacreonte, Aristófanes, Horacio, Virgilio, el Taso, el Ariosto, Boileau, Racine, Voiture, la Fontaine, Góngora, Quevedo, y otros poetas griegos, latinos, italianos, franceses y españoles, con suspensión de los que por muchos días le examinaron.» (TCU, IV, XIV, Adición, 109; 1740). Por último, ya notó Gamallo Fierros («La poesía de Feijoo», págs. 152-153) la influencia que los romances de Góngora ejercieron sobre algunos poemas de Feijoo.

66 Marañón, Las ideas..., pág. 109, n. 3. Mucha y muy valiosa información podría darnos el epistolario privado feijoniano acerca de los gustos, intereses y lecturas literarios de Feijoo, pero el pequeño número de cartas conservadas nos impide contar con tan interesante caudal de datos. 
que conocen su precio o tienen paladar proporcionado para percibir su sabor. Yo considero que infinitos se reirán de mí si en aquel romance lírico que empieza:

$$
\begin{aligned}
& \text { Lloraba la niña } \\
& \text { (y tenía razón) } \\
& \text { la prolija ausencia } \\
& \text { de su ingrato amor, }
\end{aligned}
$$

digo que se reirían de mí si me oyen que me hechiza la naturalidad de aquel «y tenía razón»; pues que si me oyen ponderar como una cosa extremadamente patética aquel como estribillo que dos veces repite la enamorada quejosa, en el mismo romance: «llorad, corazón, que tenéis razón», soltarán la carcajada y dirán que deliro.

Este testimonio resulta de suma importancia, porque con él Feijoo se integra de manera plena en la vanguardia crítica de su tiempo. En líneas generales, los autores de la generación de Feijoo no disimulan el aprecio con que miran la obra al completo de Góngora, que imitan, de hecho, de manera explícita. Es el caso de poetas como León y Mansilla, Tafalla Negrete, Butrón y Mújica, Bances Candamo o Gerardo Lobo, sin perder de vista a otros importantes autores como Torrepalma o Porcel y Salablanca, quienes no obstante erigen a Garcilaso, junto a Góngora, como su otro modelo máximo, lo que se traduce en un mayor clasicismo en sus composiciones. Es cierto que ya en 1725, en la Oración en alabanza de las obras de Don Diego Saavedra Fajardo, Mayans se lamenta de que «toda Europa desprecia i aun hace burla del extravagante modo de escribir que casi todos los españoles practican hoi ${ }^{67}{ }$, pero habremos de esperar a que en 1737 un autor de la generación siguiente a la de Feijoo, Luzán, publique la Poética, que es el primer texto dieciochesco en que aparece Góngora escindido: el oscuro e insoportable autor de los grandes poemas y el encantador y dulce lírico de arte menor:

[...] don Luis de Góngora (sea dicho sin ofensa de sus apasionados) fue uno de los que más contribuyeron a la propagación y crédito del mal estilo. Este poeta, que fue dotado de grande ingenio, de fantasía muy viva y de numen poético, pretendió señalarse por este camino raro y extraordinario, usando sin medida un estilo sumamente pomposo y hueco, lleno de metáforas extravagantes, de equívocos, de antítesis, de retruécanos y de unas transposiciones del todo nuevas y extrañas en nuestro idioma, aunque en las letrillas, romances y poesías satíricas y burlescas en

67 Citamos por Nigel Glendinning, «La fortuna de Góngora en el siglo XVIII», Revista de Filología Española, XLIV (1961), págs. 323-349; la cita en pág. 331. 
versos cortos, apartándose de aquella sublimidad afectada y acercándose más a la naturalidad, escribió mejor con particular gracia y viveza ${ }^{68}$.

De cualquier forma, a partir del juicio de Luzán acerca de Góngora que acabamos de copiar, y salvo algunas escaramuzas polémicas durante los años cuarenta promovidas por ciertos defensores del cordobés, como Juan de Iriarte, lo cierto es que Góngora fue cada vez más el autor de romances y letrillas y cada vez menos el autor de las Soledades ${ }^{69}$. No faltó, al calor del debate, algún divertido juicio como el de Luis José Velázquez, marqués de Valdeflores, quien en sus Orígenes de la poesía castellana (1754) proclamara: «en lo que mira al estilo de D. Luis de Góngora [...] solo diré que de buena gana podemos ceder a los portugueses, como a cualquiera otra nación que lo solicite, la gloria de esta invención ${ }^{70}{ }$.

\section{Quevedo, «en las manos de todos»}

Quedó ya dicho que Quevedo seguramente fuese el poeta castellano favorito de Feijoo. Él es, sin duda, el escritor español al que más a menudo se refiere en sus escritos, y posiblemente uno de los que más influencia ejerció sobre el propio estilo feijoniano. A lo largo del siglo XVIII, Quevedo no padeció la mala consideración del Góngora más culterano o del Lope comediógrafo ${ }^{71}$, y ello no

68 Ignacio de LuZÁn, La poética, edición de Russell P. Sebold, Madrid, Cátedra, 2008, I, III, pág. 172. Se impone ahora recordar que las opiniones de Luzán en contra del Barroco se radicalizan en la segunda edición de la Poética, de 1789 -62 años después de la primera edición; 45 años después de la muerte de Luzán-, que presenta cinco capítulos nuevos y múltiples correcciones a lo largo de todo el texto. Todavía hoy no está claro si dichas enmiendas se deben a la mano del propio Ignacio de Luzán o si más bien son obra conjunta de su hijo, Juan Ignacio de Luzán, y del editor del texto, Eugenio de Llaguno y Amírola, lo que ha dado lugar a un apasionante debate crítico que no necesitamos ahora reconstruir. (Cfr. Russell P. SEBoLD, «La autoría de los añadidos y cambios introducidos en la segunda edición», en su «Introducción» a Ignacio de Luzán, La poética, págs. 81-97).

69 Cuando entre 1770 y 1782 Cerdá y Rico y López de Sedano coleccionan sus tres tomos del Parnaso Español, solo incluyen, de Góngora, romances y letrillas, tal y como indica GLENDinNing, «La fortuna de Góngora...», pág. 343.

70 Luis José VeLázquez, Orígenes de la poesía castellana, Málaga, Herederos de D. Francisco Martínez de Aguilar, 1797 [1. ${ }^{\mathrm{a}}$ ed. 1754], pág. 62.

71 Aunque como poeta fuera estimado en el siglo XVIII, especialmente cuanto escribió bajo el nombre de Tomé de Burguillos, que durante un tiempo fue considerado un autor independiente - y así parece creerlo el propio Feijoo cuando se refiere a «la Gatomachia de Burguillos» (TCU, VI, X, § XXVI, 37; 1734)—, muy otra consideración merecieron sus obras teatrales. Luis José Velázquez dice de Lope que empezó «a corromper el teatro, corrupción que después fue cada día tomando más cuerpo, al paso que la nación perdía buen gusto, y las letras iban caminando a su total decadencia. Lope, fiado de su prodigiosa facilidad en el decir, y el río blando y suave de su elocuencia, despreció las reglas del teatro que nos dejaron los antiguos, desterrando de sus comedias la verosimilitud, la propiedad, la decencia, el decoro y en una palabra todo cuanto concurre a sostener la ilusión de la fábula, y a desempeñar el principal fin del poema dramático. No hay que buscar 
deja de resultar llamativo, pues, a nuestros ojos, tan barroco, en su sentido excesivo, fue Quevedo como Góngora. En este menester le sucede a Quevedo lo mismo que a Jáuregui, es decir, que el hecho de haberse opuesto a Góngora en tantas y tan encendidas ocasiones de algún modo lo exculpa y lo sitúa del mismo lado en que los autores del Siglo de las Luces se posicionaron.

Quevedo fue un autor muy editado a lo largo del XVIII, en que se dieron a imprenta no menos de nueve volúmenes de sus versos ${ }^{72}$, si bien es verdad que fue particularmente estimado por unos poemas que él en realidad no escribió, sino que solo editó, dado que por aquel entonces se pensaba que Francisco de la Torre era un seudónimo suyo ${ }^{73}$, pues se veía en ese nombre, Francisco de la Torre, una suerte de anagrama reducido de Francisco [de Quevedo, señor] de la Torre [de Juan Abad], en alusión a las heredades que Quevedo poseía al sur de la Mancha y en las que gustaba de recluirse para entregarse a la lectura. Quevedo, en fin, gozó de imitadores y propagandistas tan conspicuos en la centuria como el propio Diego de Torres Villarroel.

El propio Feijoo nos da una buena prueba de la estima que Quevedo merecía «en lo serio», pues su poesía era vista como continuadora de dos modelos muy respetados en el siglo XVIII en tanto que ideales del estilo clásico; así, Feijoo anota que, «por lo que mira al estilo de Quevedo, en lo serio», es «imitación del de Petrarca y del de Séneca ${ }^{74} »$. Parecidamente, Nicolás Fernández de Moratín y Juan José López Sedano nos ofrecen la clave debido a la que Quevedo era tan estimado por sus poemas graves, mientras se perdonaban sus excesos burlescos o lo que a buen seguro un ilustrado consideraría desmanes del ingenio: se entendía entonces que tales chistes —en El Buscón, en tantos poemas jocosos- fueron parto de sus primeros años y, en suma, pecadillos de juventud; y que, ya maduro, Quevedo emprendería las obras verdaderamente propias de su altura ${ }^{75}$.

\footnotetext{
en sus comedias las unidades de acción, tiempo y lugar: sus héroes se ven nacer, andar en mantillas, crecer, envejecer y morir. Vagan, como perdidos, desde oriente a poniente, y desde el septentrión al mediodía: y llevándolos como por el aire, aquí les hace dar una batalla, allí galantear, acullá se hacen frailes, en otra parte mueren y aún se representan sus milagros después de haber fallecido. Una escena es en Flandes, otra en Italia, México, en España y en África. Los lacayos hablan como cortesanos, los príncipes como rufianes, las damas principales como mujeres sin crianza y sin decoro. Sus actores salen al teatro como forzados, de tropel, y armados en escuadrones, siendo muy frecuente haber en sus comedias 24 y 30 personas, y aun 70 , como sucede en la del Bautismo del Príncipe de Fez, en que por parecerle corto ese número quiso añadir una procesión por remate» (Velázquez, Orígenes..., págs. 90-91).

72 Emilio Palacios Fernández, «Los poetas de nuestro Siglo de Oro vistos desde el siglo XVIII», II Simposio sobre el Padre Feijoo y su siglo, Centro de Estudios del Siglo XVIII, Oviedo, 1981, vol. II, págs. 517-543; el dato concreto en pág. 539, n. 72.

73 Palacios Fernández, «Los poetas de nuestro Siglo de Oro...», págs. 540-541.

74 Mestre, «Correspondencia Feijoo-Mayans...», pág. 154.

75 Palacios Fernández, «Los poetas de nuestro Siglo de Oro...», pág. 540.
} 
Con todo, no debe pensarse que el Quevedo más corrosivo no fuera igualmente influyente en el siglo XVIII. Feijoo mismo acusa en su propio verso la lectura del Quevedo más burlesco y desengañadamente festivo, por ejemplo en su soneto sobre el tema de Apolo y Dafne:

De Dafne amante, Apolo la seguía y sus prerrogativas le intimaba; ser el dios de la ciencias ostentaba, a lo cual Dafne más veloz huía.

«Soy músico y poeta», le decía, lo que, impaciente, Dafne le escuchaba; ser médico también le aseguraba: tanto peor, un viento parecía.

¡Oh mentecato Apolo! Si dijeras: «yo soy quien en las minas hago el oro», y de ese metal rico le ofrecieras

cantidad para hacer un buen tesoro, rendida entonces a la ninfa vieras postrar a tus promesas su decoro ${ }^{76}$.

El poema de Feijoo sigue la estela de varios otros sonetos de Quevedo en los que puede percibirse una relectura satírica y degradante del mito de Apolo y Dafne (es el caso de «Bermejazo Platero de las cumbres...» y «Tras vos un alquimista va corriendo...» ${ }^{77}$ ). Aquí podemos ver cómo un Apolo que sucesivamente va encarnando distintos atributos ilustrados (ser el dios de la ciencia, ser músico, poeta y médico, aunque en este último caso quizá se deje leer más bien el rechazo que los malos galenos producían a Quevedo y Feijoo) cosecha cada vez más animadversión por parte de Dafne, que huye de su enamorado más cuanto más letrado pretende este mostrarse. Al final, los tercetos concluyen que el modo en que Apolo hubiese conseguido conquistar a Dafne hubiera sido exhibir sus pingües riquezas, solución esta que Quevedo también utilizaba en

76 Areal (ed.), Poesías inéditas del P. Feijoo, pág. 27.

77 Francisco de Quevedo, Poesía varia, edición de James O. Crosby, Cátedra, Madrid, 1994, págs. 363-366. 
los dos sonetos mencionados sobre el mismo tema («Volvióse en bolsa Júpiter severo; / levantóse las faldas la doncella...», etc.).

No es este el único texto en que Feijoo sigue de cerca a Quevedo, pues lo hace igualmente en aquellos de sus poemas que consisten en fieras embestidas contra escritores o poetas rivales y que remedan aquellos otros con que Quevedo fue punteando su duelo con Góngora. Se trata de poemas feijonianos como «Descubrimiento del autor de un entremés satírico», «Jeroglíficos en que se pinta al autor del entremés que publicamos», «Apología a un poeta inepto y mordaz que hay en Oviedo» y «Romance a un murmurador ${ }^{78}$; sin perder de vista los poemas que supuestamente Feijoo dirige a su impugnador Francisco Soto y Marne y que algunos han creído escritos por Sarmiento: nos referimos a la décima «Al archifalsario escribiente $\mathrm{P}$. Soto y Marne» y el soneto «Plaza, que a plaza sale un balandrón...» ${ }^{79}$. Hay que añadir, por último, que algunos poemas atribuidos a Feijoo presentan en ocasiones tan irreverente contundencia burlesca que hay quien ha dudado que se debieran a la mano del benedictino, como sucede con el poema «A una dama que vendió un buey con un asta rota y pegada con trementina ${ }^{80}{ }_{»}$.

El caso es que, como apuntábamos, la prosa de Quevedo es muy recurrentemente aludida en los ensayos de Feijoo. Muy a menudo Feijoo se vale de testimonios quevedescos críticos con los médicos (TCU, I, V, 61; TCU, II, XV, 17; 1726; CEC, I, XV, 5; 1742; JR, «Motivo del P. Soto para escribir contra mí», § VIII, Reflexión IV; 1749), e incluso defiende también cierta idea de Quevedo, a saber: que los médicos no cobren si no han hecho bien su trabajo. Para esto, no se omite la relación de alguna divertida anécdota, como cuando refiere Feijoo que

[...] de Don Francisco de Quevedo se cuenta generalmente el chiste de que estando enfermo y habiéndole ordenado el médico una purga, luego que esta se la trajo de la Botica, la echó en el vaso que tenía debajo de la cama. Volvió el médico a tiempo que la purga, si se hubiese tomado, ya habría hecho su efecto; y reconociendo el vaso, para examinar, según se practica, la calidad del humor purgado, luego que percibió el mal olor del licor que había en el vaso, exclamó (como para

78 Areal (ed.), Poesías inéditas del P. Feijoo, págs. 39, 43, 45 y 47.

79 José Miguel Caso González y Silverio Cerra SuÁrez, Benito Jerónimo Feijoo. Obras completas. Tomo 1: Bibliografía, Oviedo, Cátedra Feijoo-Centro de Estudios del Siglo XVIII, 1981, pág. 147.

80 Es este un asunto que no tenemos tiempo de tratar ahora, pero que habrá que considerar en el estudio de la poesía de Feijoo para establecer conclusiones definitivas. Antolín López Peláez (ed.), Las poesías de Feijoo, Lugo, G. de Castro, 1899, pág. 85: «Filis, aunque con primor / al buey el asta pusiste / ¿qué importa, si no pudiste / pegársela al comprador? / Muy poco ingenio, en rigor, / para esto es menester, / cuando al hombre de más ser con su astucia y con su dolo / muchos cuernos, no uno solo, / pone cualquiera mujer». 
ponderar la utilidad de su receta): ¡Oh, qué humor tan pestifero! ¿Qué había de hacer éste dentro de un cuerpo humano? A lo que Quevedo replicó: Y aun por ser él tal no quise yo meterle en mi cuerpo» (TCU, VI, X, 6; 1734; parecidas anécdotas se refieren en TCU, VI, X, 7; 1734 y TCU, VI, X, 8, 9; 1734).

Quevedo también es aducido por Feijoo como autoridad para criticar a los sastres $^{81}$, a los avaros (CEC, IV, IXX, 9; 1753), para declarar que ciertas discretas invenciones fueron muy perniciosas para el hombre, como la pólvora ${ }^{82}$, para poner en solfa las aficiones musicales de los portugueses ${ }^{83}$, para probar el miedo que los cometas ocasionaban ${ }^{84}$ y para defender a Epicuro ${ }^{85}$.

Pero volvamos al Quevedo poeta, que Feijoo leía con mucha atención y no sin cuidado filológico. De tal forma lo hacía, que Feijoo llega a identificar la genealogía de «aquel excelente hipérbole suyo», «érase un hombre a una nariz pegado», que detecta leyendo una vieja anécdota de Cicerón referida por Macrobio. Nos explica Feijoo que

Lentulo, marido de Tulia, hija de Cicerón, era de muy corta estatura. Viendo en una ocasión su suegro que traía ceñida una espada grande, preguntó festivamente: Quis huic gladio generum meum alligavit? [Macrobio, Saturnalia, II, 3: ¿Quién ha atado a mi yerno a esta espada?]. La materia es en parte diferente, la agudeza la misma» (TCU, VI, X, 10; 1734).

81 Feijoo alude a la mala fama de los sastres, extremadamente avariciosos según el tópico. Se explica que, de hecho, Quevedo llamaba a los salteadores de caminos «Sastres monteses» [En «El sueño de las calaveras» habla Quevedo de los «salteadores [...], sastres silvestres y monteses»: Francisco DE Quevedo, Los sueños, edición de Ignacio Arellano, Madrid, Cátedra, 1991, pág. 419] (CEC, III, I, 9; 1750).

82 Feijoo se apoya para ello en unos versos de Quevedo: «De hierro fue el primero, / que violentó la llama / en cóncavo metal, máquina inmensa: / fue más que todos fiero, / indigno de las voces de la fama» [«En cárcel de metal, oh atrevimiento...», vv. 60-64], en los que está presente la misma idea (TCU, VI, I, Paradoja primera, $2 ; 1734)$.

83 Se reproduce un romance satírico de Quevedo en el que, «con la gracia que en todo», alude a las aficiones musicales de los portugueses (a la «guitarrilla», fundamentalmente), que Feijoo sustenta con su propia experiencia y sus recuerdos: «A tener alma melosa, / fuera portugués machín, / por hartarme de bayeta, / y para dar que reír. / Mas no quiero llorar muerto / al Rey valiente e infeliz, / que de guitarra en guitarra, / se fue llegando al Sofí» [«Censura costumbres y las propiedades de algunas naciones», vv. 108-116] (CEC, II, VIII, 26; 1745).

84 Hablando del miedo que los Cometas inspiraban a las gentes, se refiere Feijoo al pavor que en particular infundían a los Príncipes y Monarcas, pues era fama que «contra sus vidas se dirigen principalmente las iras de aquella maligna llama, como si el cometa tuviese alguna especial ojeriza con el Cetro»; se reproduce entonces una burla de Quevedo, hecha «con suma graciosidad», sobre este menester en el soneto que empieza: «Si el Cometa viniera por Coronas, / ni Clérigo, ni Fraile nos dejara, / y el tal Cometa irregular quedara / en el ovillo de las cinco Zonas» [«Desacredita la presunción vana de los cometas», vv. 1-4] (CEC, III, XXXI, 29; 1750).

85 Quevedo es aducido como auctoritas en la defensa de Epicuro. Omite Feijoo aludir al pasaje concreto en que Quevedo emprende su defensa de Epicuro de nuevo porque «las obras de Quevedo andan en las manos de todos»(TCU, VI, II (Epicuro), 24; 1734). Revisa seguidamente Feijoo algunos testimonios favorables a Epicuro que Quevedo no recoge en su obra sobre tal menester (TCU, VI, II (Epicuro), 26; 1734). 
Asimismo, Feijoo propone la recóndita fuente que Quevedo siguió en sus quintillas «Al polvo de un amante que en un reloj de vidrio servía de arena a Floris, que le abrasó», incluidas en el corpus de poemas quevedescos dispuestos bajo la advocación de la musa Calíope. Según Feijoo, Quevedo reelabora un epigrama neolatino del italiano Jerónimo Amaltheo (CEC, II, VII, 22, 23; 1745). Feijoo se refiere al poema que comienza: «Este polvo sin sosiego / a quien tal fatiga dan...», y no se equivoca al proponer la influencia de Hieronimo Amalteo (1507-1574) —así suele transcribirse hoy su nombre-, como ha probado Eugenio Asensio ${ }^{86}$, quien en su estudio al respecto allega y traduce los epigramas latinos de Amalteo y estudia su relación con el poema de Quevedo, aunque sin aludir para nada a Feijoo.

Además, ya por último, se deja oír en la prosa feijoniana la música de la intertextualidad quevedesca, pues se sirve el benedictino de una feliz enálage de Quevedo: «Sin duda que este diablo (por usar palabras de Quevedo) no sabe lo que se diabla» (TCU, VIII, VI, 31; 1740) [Feijoo alude a la oración «Ese es tonto y no sabe lo que se diabla», del opúsculo quevediano en prosa El Entrometido y la Dueña y el Soplón $\left.{ }^{87}\right]$.

\section{Bernaldo de Quirós, «Fénix que habrá de resucitar»}

El asturiano Francisco Bernaldo de Quirós, es, por último, una de las debilidades líricas de Feijoo. De hecho, es la principal esperanza poética de Feijoo en su tiempo, lo que no deja de resultar cuando menos llamativo, habida cuenta de la enorme dureza con que se pronuncia acerca de los poetas de su época (TCU, I, XIV, § XII, 45-52; 1726; CEC, II, VII, 34; 1745; CEC, II, VIII, 13-20; 1745), lo que en nada obsta para que a él le dedique infrecuentes y encendidos elogios:

El genio poético que resplandeció en los españoles antiguos se conserva en los modernos. Majestad, fuerza, elevación son los caracteres con que los sella la nobleza del clima. El siglo pasado vio Manzanares más Cisnes en sus orillas que el Meandro en sus ondas. Hoy no se descubren iguales ingenios. Digo que no se descubren; no que no los hay. O se ocultan los que son dotados de valentía de numen o no quieren cultivar una facultad que sobre estar desvalida respecto del vulgo constituye el juicio sospechoso; pero no carece de toda excepción esta regla. Entre

86 Eugenio AsENSIO, «Reloj de arena y amor en una poesía de Quevedo (fuentes italianas, derivaciones españolas)», Dicenda, 7 (1987), págs. 17-32.

${ }^{87}$ Francisco De Quevedo, El Entrometido y la Dueña y el Soplón, edición de Miguel Marañón Ripoll, Fundación Universitaria Española, Madrid, 2005, pág. 50. 
las desapacibles voces de muchos grajos se ha oído aún en esta era la melodía de uno u otro canoro cisne. Este país produjo uno muy singular en la persona de Don Francisco Bernardo de Quirós, Teniente Coronel del Regimiento de Asturias» (TCU, IV, XIV, § XV, 44; 1730).

Y a continuación prosigue, de nuevo sin escatimar parabienes, refiriendo que

[...] fue Don Francisco Bernardo de Quirós y Benavides, natural de este país y de la primera nobleza de él, Teniente Coronel del Regimiento de Asturias, que murió lastimosamente de edad temprana en la batalla de Zaragoza. Era sujeto de exquisita vivacidad y penetración, de portentosa facilidad y elegancia en explicarse, de admirable facultad memorativa, insigne poeta, historiador, humanista, matemático, filósofo. Sobre todo, la valentía de su numen poético y la gracia y agudeza de su conversación, tanto en lo festivo como en lo serio, excedían a cuanto yo puedo explicar. Certifico que las pocas veces que logré oírle me tenía absorto y sin aliento para hablar una palabra, tanto por no interrumpir la corriente de las preciosidades que derramaba, cuanto por conocer que todo lo que yo podría decir parecía cosa vil a vista de la variedad y hermosura de sus noticias, juntas con la facilidad, energía y delicadeza de sus expresiones. (TCU, IV, XIV § XXIII, 83; 1730).

Lamentablemente, carecemos hoy de testimonios como para poder ratificar el apasionamiento de Feijoo, pues únicamente conservamos un poema de Bernaldo de Quirós, «El caballu», escrito en asturiano e incluido por Caveda y Nava en su famosa antología ${ }^{88}$. Álvaro Ruiz de la Peña, que es seguramente quien más atención ha venido dedicando a la figura de Bernaldo de Quirós ${ }^{89}$, especulaba ya en 1980 con la posibilidad de que Bernaldo de Quirós hubiese escrito también en español, lo que justificaría la admiración de Feijoo, quien nunca afirma que leyese en asturiano, y quien parece dar por hecho que Bernaldo de Quirós escribía en castellano (¿no lo hubiera precisado de no ser así?). Esta posibilidad apuntada por Ruiz de la Peña es ratificada por González de Po-

88 Francisco Bernaldo de Quirós, «El caballu», en Xosé Caveda y Nava, Colección de poesías en dialecto asturiano, edición facsímil, prólogo de José Miguel Caso González, Oviedo, Alvízoras, 1989 [1. a ed. 1839], págs. 79-91.

89 Para todo lo relacionado con Bernaldo de Quirós, puede verse: Álvaro RuIz DE LA PeÑA, «Referencias asturianas en el Teatro Crítico y en las Cartas Eruditas», II Simposio sobre el Padre Feijoo y su siglo, Oviedo, Cátedra Feijoo, 1981, vol. I, pág. 471; Álvaro RuIZ DE LA PEÑA, Introducción a la literatura asturiana, Gijón, Ayalga, 1981, págs. 43-48; y Álvaro RuIz dE LA PEÑA, La hora de Asturias en el siglo XVIII, RIDEA, Oviedo, 2012, págs. 388-394. También es de gran interés José Ramón ToLivar FAEs, «"El caballo”, romance en bable de Don Francisco Bernaldo de Quirós», Boletín del Instituto de Estudios Asturianos, 96-97 (1979), págs. 127-152. 
sada, quien afirma haber leído en su juventud poemas castellanos de Bernaldo de Quirós, por ejemplo «El soliloquio amoroso», que luego encontró atribuidos a Eugenio Gerardo Lobo $^{90}$. En cualquier caso, quizá «El caballu» sirva para hacernos idea del talento de Bernaldo de Quirós; Xuan Xosé Sánchez Vicente, editor de la antología de Caveda, afirma que este poema es «en sin duda, el meyor poema de la antoloxía y, quiciavis, de la lliteratura asturiana», juicio este que, no obstante, Ruiz de la Peña se apresura a matizar, considerándolo «de una contundencia desaconsejable, por la gratuita descalificación del resto ${ }^{91}{ }_{»}$.

Más nos interesa la valoración estética de «El caballu», en tanto ello pudiera orientarnos al respecto del interés de Feijoo por la obra de Bernaldo de Quirós. Explica Ruiz de la Peña que se trata de un poema que todavía podría recogerse bajo el palio de la escuela barroca, pero que aparece ya purgado de excesos retóricos. No es difícil percibir bajo esta descripción el gusto literario de Feijoo, quien defendió una poesía lo más natural posible pero nunca exenta de gracia y numen; apunta Ruiz de la Peña que aunque no se hallen en «El $c a-$ ballu» violencias sintácticas ni agresivas transposiciones expresivas, todavía se dejan ver «imágenes, metáforas e hipérboles» en abundancia ${ }^{92}$.

Feijoo se refiere en TCU, IV, XIV § XXIII, 83; 1730 a la pronta muerte de Bernaldo de Quirós. También le dedicó un poema epitáfico, que aquí copiamos, en el que se deja sentir igualmente la altísima estima en que lo tenía ${ }^{93}$ :

\author{
Epitafio a D. Francisco Bernaldo de Quirós, poeta \\ Un portento yace aquí \\ de discreción y agudeza, \\ en quien la naturaleza \\ dio cuanto pudo de sí. \\ Porque fue tan singular, \\ menos sensible es su muerte; \\ pues siendo Fénix se advierte \\ que habrá de resucitar ${ }^{4}$.
}

90 Citamos por Ruiz de la Peña, La hora de Asturias..., págs. 389-390.

91 Ambas citas en Ruiz de la PeÑa, La hora de Asturias..., pág. 390.

92 Ruiz de la Peña, La hora de Asturias..., pág. 391.

93 Francisco Bernal de Quirós debió de nacer en torno a 1680, y luchó en la guerra dinástica de 1701-1714 del lado de los Borbones; murió en 1710 en la batalla de Zaragoza (RuIz DE LA PeÑa, La hora de Asturias..., págs. 388-389).

94 Areal (ed.), Poesías inéditas del Padre Feijoo, pág. 59. 
Dejando ahora a un lado a los autores concretos, se impone incidir en la importancia de la nómina de poetas españoles dada por Feijoo. Es dudoso hablar de la trascendencia del canon feijoniano, pues la generación ilustrada no citará como tales los pareceres del de Casdemiro aunque coincida con ellos, pero sí podemos hablar de la novedad y la primacía del canon de Feijoo. A la postre, lo importante es que los Mendoza, Garcilaso, Solís, Quevedo, Góngora (en arte menor), Argensola, Jáuregui, Lope de Vega y Calderón que Feijoo nombra se corresponden paladinamente con los poetas citados por los autores de la generación ilustrada.

Es en el medio siglo cuando comienza a fraguarse, en distintos recuentos históricos de la poesía española, el conjunto de poetas que empezaron a constituir objeto de imitación. En sus Memorias para la historia de la poesía y poetas españoles (escritas aproximadamente en 1745, pero publicadas de manera póstuma treinta años después) fray Martín Sarmiento acude a Garcilaso de la Vega, Gregorio Silvestre, Quevedo, Góngora y Lope de Vega como sus poetas de referencia ${ }^{95}$. Trascendencia fundamental alcanza indudablemente Luis José Velázquez con sus sobredichos Orígenes de la poesía castellana (1754), obra en la que ensalza principalmente a tres figuras, Garcilaso, fray Luis y Villegas, sin perder de vista a Quevedo, «principalmente las poesías que publicó con el nombre supuesto del Bachiller Francisco de la Torre ${ }^{96}$ ». Idéntica idea manifiesta también Luzán, si bien en un añadido incluido en la edición de 1789 de la Poética ${ }^{97}$.

Otros historiadores del momento perfilan y apuntalan una pléyade hispana semejante. Los hermanos Rodríguez Mohedano en la Historia literaria de España desde su primera población hasta nuestros días (1766) destacan a Garcilaso, Boscán, Padilla y Argensola; Francisco Javier Lampillas, en su Saggio storico-apologetico della letteratura spagnoula (1778-1781), a Garcilaso, fray Luis, Herrera, los Argensola, Quevedo, Lope de Vega Villegas y Góngora, aunque con algún reparo, entre otros a los que acaso no concede tanta atención; y Juan Andrés, en su Dell'origine, progressi e stato attuale d'ogni letteratura (1782-1799), principalmente a Garcilaso, fray Luis, Villegas y, no sin ciertos reproches, a Lope, Góngora, Quevedo y Calderón ${ }^{98}$.

95 Debe hacerse notar que Sarmiento «no pretende construir una historia literaria cabal y sistemática [...], sino más bien reunir en forma de "apuntamientos" todos los materiales y noticias que ha conseguido allegar para forjar el itinerario temporal de la literatura hasta los Reyes Católicos». Inmaculada URZAINQUI, «El Parnaso español en la historia literaria del siglo XvıII», Bulletin Hispanique, 109, 2 (2007), págs. 648-649. Para todo lo relacionado con las Memorias de Sarmiento, véanse las págs. 648-652.

96 Velázquez, Orígenes..., pág. 58.

97 LuZÁn, La poética, II, II [1789], págs. 228-229.

98 Urzainqui, «El Parnaso español...», págs. 659-684. 
En definitiva, lo citen o no, el feijoniano es uno de los testimonios más tempranos a la hora de fijar el canon poético español que el siglo XVIII perpetuará, pues el suyo es el núcleo de poetas preferidos por los grandes autores neoclásicos españoles, al que solo añadirán unos pocos nombres (fundamentalmente, Villegas, Francisco de la Torre, Fernando de Herrera y, en menor grado, Ercilla). Cadalso, por ejemplo, cuenta entre sus poetas predilectos mayoritariamente a Garcilaso, fray Luis, Lope, Quevedo y los recién mencionados Villegas, Herrera y Francisco de la Torre ${ }^{99}$; Jovellanos, por su lado, en carta a Carlos González de Posada le hace notar que los más «escogidos» modelos en materia de versos son Garcilaso, Herrera y fray Luis ${ }^{100}$; finalmente, el catálogo de los poetas leídos por Meléndez Valdés entre 1777 y 1780 arroja el siguiente saldo, muy parecido: Argensola, Boscán, Ercilla, Garcilaso, Quevedo, Lope de Vega, Villegas y Góngora, bien entendido que de este último había leído solo varios romances ${ }^{101}$.

Los poetas europeos

Comparando el ingenio de las distintas naciones (TCU, I, XV; 1726), Feijoo propone una serie de observaciones acerca de la poesía francesa, italiana y española. Según Feijoo, los franceses perciben la poesía italiana y la española como excesivamente hiperbólicas; sin embargo, él es de la opinión de que los franceses «por afectar ser muy regulares en sus pensamientos, dejan sus composiciones muy lánguidas. Cortan a las musas las alas o con el peso del juicio les abaten al suelo las plumas» (TCU, I, XV, § VI, 32; 1726) ${ }^{102}$; ahora bien, no

99 François Lopez, «La generación de 1780 y sus parnasos», Bulletin Hispanique, 109, 2 (2007), págs. 709-747; la cita en pág. 731.

100 Gaspar Melchor de Jovellanos, «Carta a Carlos González de Posada del 28 de junio de 1800», Obras completas III, Correspondencia II, edición de José Miguel Caso González, Oviedo, Centro de Estudios del Siglo XVIII, 1986, pág. 539.

101 Georges Demerson, Meléndez Valdés (2 vols.), Madrid, Taurus, 1971 [1. a ed. francesa de 1962], vol. I, págs. 105-111.

102 No muy afín a la poesía francesa se manifiesta también cuando nos dice en su Menangiana que «es casi inevitable omitir, a excepción de una u otra cosita, todo lo que hay de poesía francesa, que es mucho; ya porque los pensamientos poéticos de los franceses no son muy del gusto de los españoles, ya porque no corresponde el gusto de leerlos a la fatiga de traducirlos» (CEC, II, VII, 2; 1745). Aún más claro se mostrará después: «he notado que como haya algo de genio para traducir el verso francés a nuestro idioma y metro, parece mejor la copia que el original. Los franceses están muy satisfechos de su poesía. Yo nunca pude hallar sino un sabor muy tibio en ella. No puedo negar que algunos de sus poetas piensan con mucha delicadeza; pero el traje con que visten sus pensamientos es desairado. Los pies de que comúnmente usan son ya de doce sílabas, ya de nueve. En los primeros siento una cadencia floja; en los segundos, desabrida» (CEC, II, VII, 50; 1745). Para todo lo referido con las fuentes francesas y las alusiones a autores galos de Feijoo sigue siendo de trascendental importancia el estudio clásico de Gaspar DelPy, Bibliographie des sources françaises de Feijoo, París, Hachette, 1936. 


\section{Poetas franceses, italianos y portugueses citados por Feijoo}

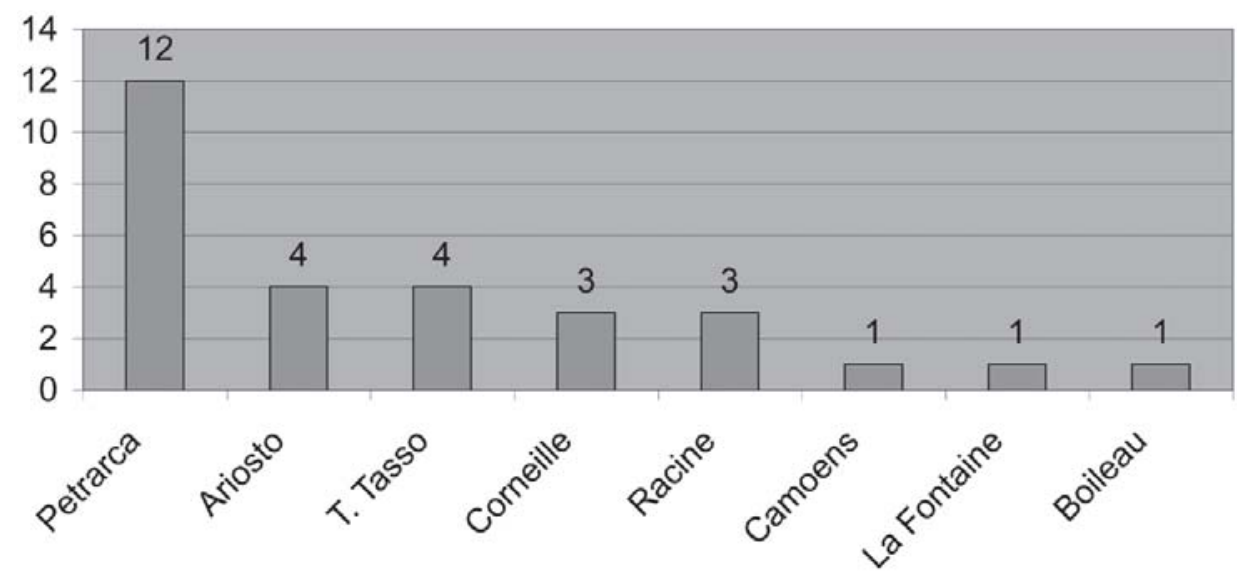

debemos olvidar que Feijoo valoraba muy especialmente la naturalidad de la poesía francesa, pues en ella «el arte está amigablemente unido con la naturaleza» (TCU, I, XV, § III, 13; 1726).

Con todo, no nos extrañará, ahora, saber que Feijoo manifiesta una especial querencia por la poesía italiana, particularmente por Torquato Tasso (1544-1595; Feijoo lo grafía siempre Taso), que es uno de los poetas italianos más citados y del que más versos comenta y traduce ${ }^{103}$. Feijoo considera que no hay ninguna poesía que se pueda acercar, en lo que a la calidad musical se refiere, a la italiana. Más aún, concede preeminencia a la nación italiana en las artes del gusto: «es preciso dejar a salvo, por lo menos en cuanto a la práctica, los grandes créditos de la Italia; pues por más que comúnmente los franceses, aun en estas artes,

103 Primeramente nos dice Feijoo que «después de los poemas de Homero y Virgilio no hay cosa que iguale en el género [poesía épica] a la Jerusalén del Taso» (TCU, I, XV, § VI, 31; 1726); después, Tasso es citado como autoridad (TCU, IV, XIV, Adición, 109; 1740); por último, se citan y traducen varios versos suyos especialmente lúcidos: primero (CEC, II, VII, 63; 1745), los versos «Manca il parlar, di vivo altro non chiedi; / Ne manca quaesta ancor, s'agli occhi credi» (Jerusalén, Canto XVI, Octava II, vv. 7-8), que Feijoo traduce como «Solo por mudo desdice / de vivo este raro asombro; / mas ni aun el alma le falta / si es que se cree a los ojos» (CEC, II, VII, 64; 1745); luego (CEC, II, VII, 65; 1745) el verso «no (...) menos hermoso» «Saró qual piú vorrai, scudiero, o scudo» (Jerusalén, Canto XVI, Octava L, v. 1), que Feijoo traduce como «Nada en exponerme dudo / delante de las hileras; / y seré lo que tú quieras,/ o tu escudero, o tu escudo» (CEC, II, VII, 65; 1745); finalmente (CEC, II, VIII, 67; 1745) Feijoo elige el verso «Brama asai, poco spera, è nulla chiede» (Jerusalén, Canto II, Octava XVI, v. 4) y lo traduce por «Es el amor de Alcino / ardiente, pero humilde, / pues deseando mucho, / poco espera de Celia, y nada pide». Feijoo también hace alusión a Sannazaro; por ejemplo, reproduciendo y glosando un divertido epigrama suyo (CEC, II, VIII, 83; 1745). Con ello, y con alguna alusión no muy admirativa a Ariosto a causa de los excesos fabuladores de su Orlando furioso (TCU, IV, XIV, § XV, 39, Adición, 15), se acaban las alusiones de Feijoo a la poesía italiana. 


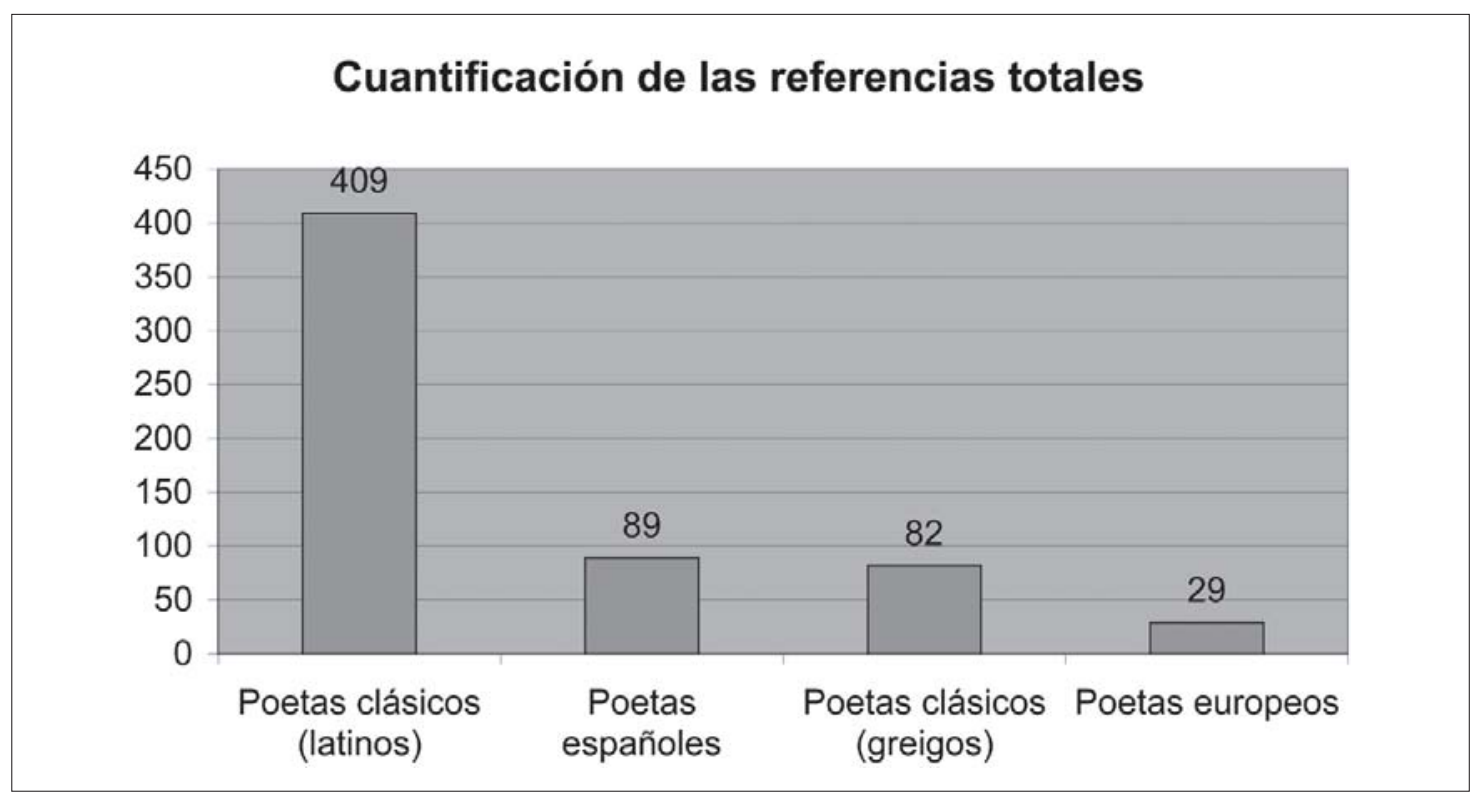

quieran atribuirse algunas ventajas considerables, creo que todos sus poetas no hacen un Torquato Taso» (CEC, V, XXIII, § VII, 36; 1760). Entre los poetas italianos, por cierto, Feijoo también concede atención a Petrarca, a quien cita una docena de veces. Feijoo tiene en cuenta a Petrarca como el filólogo ilustre que fue y lo pondera como el gran autor moderno de Italia, equivalente a Quevedo en España (TCU, I, V, § XI, 61; 1726). Dedica también Feijoo una bella página a reproducir la leyenda amorosa de Petrarca y a glosar algunos de sus versos ${ }^{104}$.

Ahora bien, apunta Feijoo que lo mismo la poesía francesa que la italiana son naturales, pero

[...] la de los franceses es una naturalidad lánguida; la de los italianos, brillante. Este es el punto de mayor dificultad en la poesía, unir la gala, la hermosura, la valentía con la naturalidad. Esto es propio de los grandes genios y que se niega a todos los conatos de la aplicación y el estudio. [...] En los italianos veo menos hermosa la prosa y mucho más brillante el verso. Así yo suelo decir que me den prosa francesa y poesía italiana (CEC, II, VII, 50; 1745).

104 Cuenta Feijoo: «¿qué diré del Petrarca, reconocido por el P. Felipe Labbé, y aun por todos, por el Príncipe de su siglo en ingenio y elocuencia, tan pasado de amor por la bella y sabia francesa Laura, que treinta años que vivió después que la vio y trató cerca de Aviñón (y los últimos diez ya era muerta), no hizo más que cantar y gemir por ella?» (TCU, VII, XVI, § I, 5; 1736). «Pregunto ahora: ¿cuántas veces se le renovaría toda la sangre al Petrarca en los treinta años que vivió después que conoció a la bella Laura? El amor sin embargo vivió en él mientras él vivió, sin que la estación fría de la senectud minorase su ardor, como él mismo testificó cuando dijo que se le iba mudando el cabello (esto es, de negro a blanco), sin poder mudar su obstinada pasión: Que vó cangiando il pelo / ne cangiar posso l'ostinata voglia» [Cancionero, CCCLX, vv. 41-42: Que voy cambiando el pelo / sin cambiar el deseo que me oprime] (TCU, VII, XVI, § III, 11; 1736). 
Como antes anotamos, hay más «entusiasmo» («gala, hermosura, valentía») en la poesía francesa y de ahí su preferencia.

Dispongamos también, aquí, por último, la única alusión feijoniana a la poesía portuguesa que hemos encontrado: en CEC, IV, «Dedicatoria a la Reina nuestra señora Doña Bárbara de Portugal»; 1745, como de pasada, alude Feijoo a «la sonora voz de aquel cisne del Tajo o Virgilio lusitano, el gran Camoens».

\section{Recapitulación}

La información recogida de las citas de los poetas y su valoración a lo largo de los apartados anteriores constituye una suerte de canon muy operativo con vistas a apuntalar las preferencias estéticas feijonianas. Así, podemos observar que los modelos poéticos preferidos por Feijoo son mucho más épicos que líricos. De tal manera, Feijoo no muestra un gran entusiasmo por ninguno de los grandes poetas líricos, a quienes conceptúa a menudo como «lascivos» en exceso (Anacreonte, etc.). Los poemas amatorios de Propercio u Ovidio, que conoce bien, le interesan desde un punto de vista más científico que literario; Ovidio, de hecho, le atraerá no como el más joven de los elegíacos, sino como el autor de «los Metamorfoseos», obra que seducirá a Feijoo por su contenido enciclopédico, su erudición y su esmerado lenguaje. No es extraño, a la vista de esto, que su lírico preferido fuese Horacio, por la carga de profundidad moral que imbuye muchas de sus odas.

La épica, por su parte, le atrae porque se aproxima mucho más a la historia y porque palpita en su naturaleza el deseo de formar a una colectividad, proponiendo modelos de conducta heroicos y fomentando la creación de una conciencia de grupo entre sus receptores; así, es la épica más ligada a los sucesos históricos, paradigmáticamente representada por la Farsalia, aquella por la que Feijoo siente especial predilección, habida cuenta de que tal tipo de obras reúnen la intensidad de la lírica, la capacidad propedéutica que Feijoo considera que es propia de la poesía y el componente testimonial de la historia.

Otro género poético que por parecidos motivos interesó mucho a Feijoo fue la sátira, que admiró en autores como Marcial, Juvenal y Horacio, sin perder de vista a Quevedo. La sátira se propone reconvenir las costumbres viciosas de una colectividad, y por lo tanto actúa directamente sobre los individuos y afirma a cada paso su intencionalidad didáctica; no obstante, el peligro de la sátira radica en que su propia naturaleza la haga incurrir en la burla y en un exceso de causticidad que por su propio carácter extremo Feijoo tampoco podía aceptar; no disuena, por ello, que el de Casdemiro motejase de chocarreros ciertos 
poemas de Marcial que se extraviaban del ideal de contención que Feijoo cree apropiado para la poesía y especialmente para la sátira.

En última instancia, el benedictino también manifiesta su inclinación hacia aquellos géneros poéticos que, valiéndose del verso, pretenden emprender explicaciones filosóficas o físicas de la realidad, como Sobre la naturaleza de las cosas, de Lucrecio, o la Astrología de Manilio. Para Feijoo, ambas obras unen a su primor formal, a su inspirada constitución y a su total ausencia de elementos fabulados, su vocación utilitaria.

La elaboración lingüística es uno de los criterios que signan las preferencias poéticas feijonianas: por eso encarece tanto el tono general de la Farsalia y también algunos hallazgos concretos en la Eneida, sin ir más lejos. La espontaneidad, la elegancia y la limpieza son otros parámetros que se dejan sentir entre sus lecturas poéticas: el Góngora de los romances y las letrillas, Antonio de Solís o Bernaldo de Quirós evidencian su gusto por lo que podríamos llamar Barroco estilizado, o, si valiera el posible oxímoron, Barroco clásico. El Juicio Lunático de Porcel apunta hacia la síntesis de ímpetu del XVII y pureza del XVI que Feijoo confiesa preferir en sus lecturas y que defiende en sus comentarios poéticos. Porcel se refiere a esa misma simbiosis de naturalidad renacentista y entusiasmo barroco cuando demanda de los nuevos poetas:

[...] que nuestros Virgilios sean más divinos que el de Mantua, llenos de toda la deidad que agitó el pecho de Lucano, y que nuestros Lucanos, sufriendo más pacientes el ímpetu sacro, humanen su entusiasmo con la energía y pureza de Virgilio; que los nuevos Góngoras se ilustren con la claridad de Lope, se ciñan con la exactitud de los Argensolas; y que los nuevos Lopes, los segundos Argensolas se levanten y se divinicen con la arcanidad laboriosa de Góngora. Los nuevos Quevedos no carecerán ya de la circunspección de los Villegas y los Herreras; los nuevos Herreras no serán menos divinos por menos metafísicos ${ }^{105}$.

En resumen, resulta indudable que Feijoo pretende con sus escritos de poética defender una vuelta a la línea clásica de la literatura, buscando los referentes en que mirarse en lo más granado de la tradición latina del siglo de Augusto, a la que deben añadirse esas figuras de las literaturas española y europea que terminarán consolidándose como el canon poético de la Ilustración.

105 Nicolás Marín, Poesía y poetas del setecientos, Granada, Universidad de Granada, 1971, págs. 174-175. 


\section{Autores citados por Feijoo en relación}

\section{con sus ideas poéticas ${ }^{106}$}

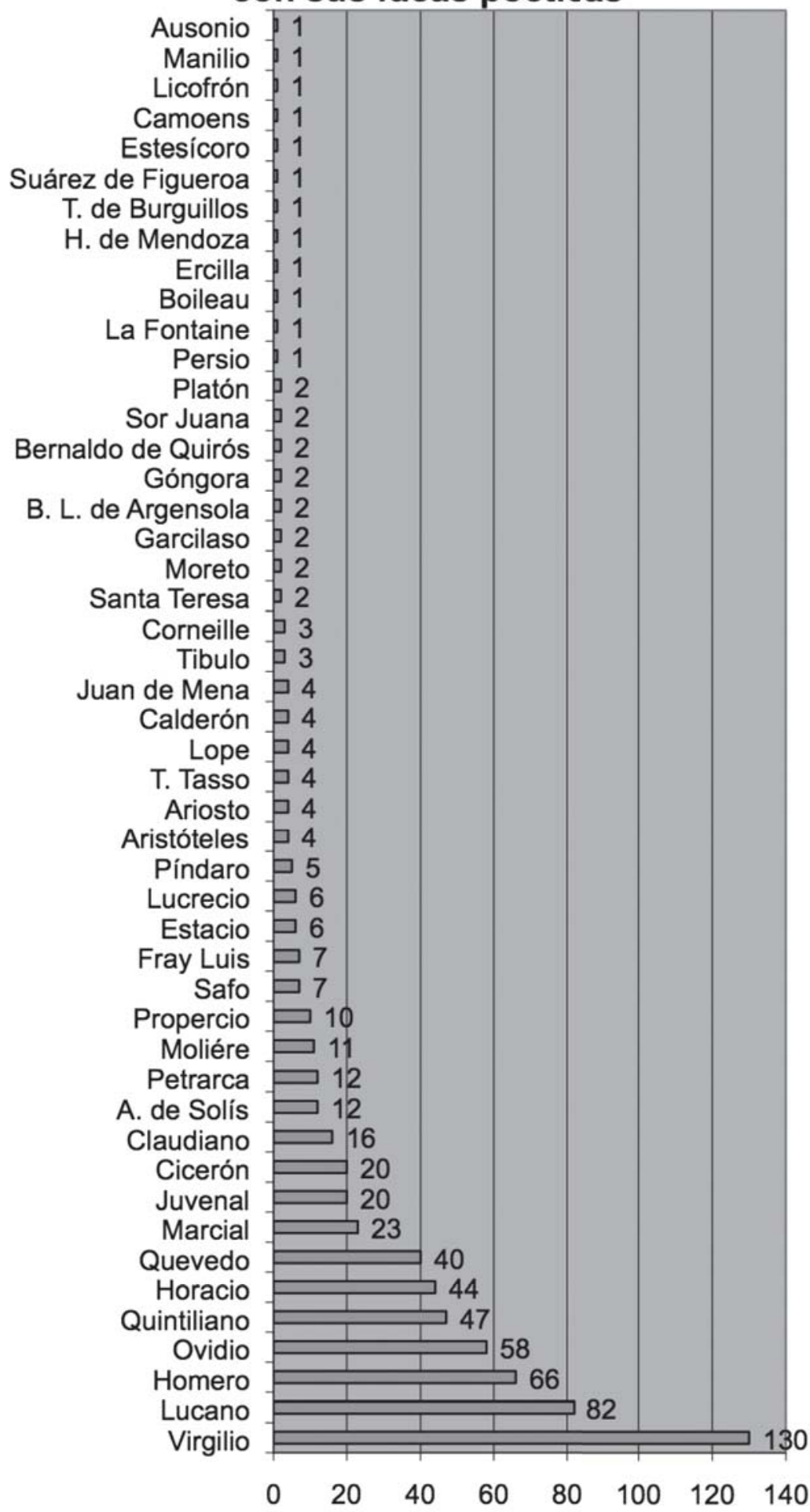

106 Para no desvirtuar la gráfica, no indicamos el cómputo total de referencias que alcanzan Cicerón, Platón y Aristóteles, sino solo el número de veces en que son aludidos para tratar temas poéticos. 